\title{
INSTITUCIONES POLÍTICAS Y FUNCIÓN JUDICIAL EN DERECHO CONSTITUCIONAL COMPARADO
}

David Landau*

A finales de la década de 1990 Colombia afrontó una crisis hide vivienda de clase media ${ }^{1}$. El presidente y el Congreso ignoraron el problema; el presidente estaba ocupado atendiendo los llamados internacionales de austeridad fiscal y el legislativo era demasiado disfuncional para actuar. La Corte Constitucional colombiana ("la Corte colombiana" o "la Corte") empezó a recibir una oleada de demandas de constitucionalidad de los propietarios de vivienda y decidió actuar. Realizó sesiones de estilo legislativo a las que invitó grupos de propietarios, banqueros, economistas y agencias estatales, y recibió innumerables informes de esos actores. Aunque su enfoque era interactivo y el proyecto final de la ley de vivienda fue redactado en gran parte por el presidente, la Corte tuvo un papel preponderante en la redacción de los detalles. Respaldada por la información bastante precisa que recibió durante su investigación, consideró que tenía información suficiente para cumplir un papel en materia de redacción de la política. La labor de la Corte, aunque imperfecta, tuvo éxito porque era muy popular y porque mantuvo en su vivienda a la mayoría de los propietarios.

* Candidato a Doctor del Departamento de Gobierno de la Universidad de Harvard, profesor asistente de Florida State University [dlandau@law.fsu.edu]. Agradezco a Christine Desan, David Fontana, Tara Grove, Daryl Levinson, Daniel Meltzer, Frank Michelman, Miguel Schor, David Schleicher, Cindy Skach, Matthew Stephenson, Mark Tushnet, Adrian Vermeule, participantes en el Comparative Law Work in Progress Workshop de la Universidad de Michigan, y a los participantes en la Northeast Law \& Society Conference, por sus comentarios y conversaciones sobre este artículo. Artículo publicado en Harvard International Law Journal 51, 2, 2010, pp. 319-377. Traducción de Alberto Supelano. Fecha de recepción: 24 de enero de 2011, fecha de modificación: 3 de mayo de 2011, fecha de aceptación: 6 de mayo de 2011.

${ }^{1}$ Ver sección III.C.1. 
¿Cómo evaluar las acciones de la Corte colombiana para enfrentar la crisis de vivienda? Según la teoría constitucional estadounidense y las prescripciones emergentes sobre el cumplimiento de los derechos económicos, sociales y culturales (DESC) en derecho constitucional comparado, sus acciones parecen muy problemáticas. La teoría constitucional estadounidense exige cierto respeto por la esfera de competencia del legislativo; ciertos campos de política deben estar fuera de los límites de las cortes y se deben seguir ciertas reglas incluso en esos campos ${ }^{2}$. Un problema de vivienda de la clase media no es un caso obvio de intervención judicial, pues la clase media generalmente tiene recursos políticos para hacer valer sus derechos. Y aun si hubiera razones para intervenir, la forma en que intervino la Corte -realizando sesiones de estilo legislativo y redactando la política de vivienda en detalle-parece ir más allá de los límites básicos del comportamiento de una corte. De manera similar, la vertiente emergente de trabajos sobre DESC arroja dudas sobre la acción de la Corte ${ }^{3}$. Esta literatura subraya que la ayuda debería ir a los grupos más necesitados y no a estratos medios. Además, conforme a esta literatura, el cumplimiento de los DESC debería lograrse con cierta deferencia: las cortes deben señalar donde ha fallado el órgano legislativo en cumplimiento de los principios constitucionales, pero deben asegurar que otras ramas del gobierno asuman el liderazgo en el diseño de políticas. La Corte colombiana ha sido más agresiva de lo que implicaría el modelo estándar de DESC.

No obstante, argumento que sus acciones se deben juzgar en el contexto institucional. Desde esta óptica, son mucho más justificables de lo que aducen la teoría constitucional estadounidense o la literatura comparada sobre DESC. Las teorías constitucionales elaboradas para analizar la labor de la Corte Suprema de Estados Unidos no son adecuadas para su exportación directa al contexto comparativo, al menos al mundo en desarrollo. Dicho brevemente, debido a que la teoría constitucional estadounidense se basa en un conjunto de supuestos sobre las instituciones políticas que no se cumplen en muchas democracias del mundo en desarrollo. A nivel más básico, los constitucionalistas estadounidenses y los teóricos de los DESC comparados suponen que existe una esfera de política que se debe reservar al legislativo y someter al proceso democrático, al menos en ausencia de una justificación especial. Los teóricos no concuerdan en la amplitud de esta esfera ni en el tipo de justificaciones que permi-

\footnotetext{
${ }^{2}$ Ver sección I.A.

${ }^{3}$ Ver sección I.B.
} 
ten la intervención judicial, pero concuerdan en que hay un espacio exclusivo que se debe dejar al cuerpo legislativo.

Este supuesto básico es válido en algunos contextos pero es problemático en otros, en particular en democracias del mundo en desarrollo. En primer lugar, muchos teóricos suponen que otras instituciones políticas se preocupan por la Constitución cuando diseñan sus políticas; esto requiere una "cultura constitucional", al menos entre las élites. Aunque damos por supuesta dicha cultura en Estados Unidos, es rara en el resto del mundo. En segundo lugar y más importante, las instituciones políticas deben funcionar bien en un sentido básico: han de tener la capacidad y la legitimidad democrática para representar al "pueblo" de la manera que esperamos normalmente en una democracia. Pero en muchos países en desarrollo el cuerpo legislativo carece de la capacidad y la legitimidad democrática mínimas, debido ante todo a problemas del sistema de partidos. Cualquier intento de construir una teoría del rol judicial en esos países debería comenzar por tanto con una evaluación comparativa de sus instituciones políticas, y no con teorías tomadas en préstamo de Estados Unidos. Este artículo adhiere entonces a una corriente académica reciente sobre derecho público que toma en cuenta la importancia de las instituciones políticas, especialmente de los sistemas de partidos, para el derecho constitucional $1^{4}$.

E1 núcleo de este artículo es un estudio de caso de la Corte Constitucional colombiana desde su creación en 1991. Colombia es un ejemplo clásico de un país en desarrollo que es democrático (de hecho, ha sido democrático durante largo tiempo) ${ }^{5}$, pero que sufre de un mal funcionamiento de las instituciones políticas. En particular, el sistema de partidos es muy débil: el sistema es fragmentado, los partidos tienden a ser de corta vida o a tener facciones internas y tienen débiles raíces en la sociedad. En consecuencia, el cuerpo legislativo nunca ha podido cumplir un papel constructivo en el diseño de políticas y los presidentes han dominado en el proceso de diseño de políticas.

Como mostraré más adelante, la Corte Constitucional colombiana considera que estas condiciones políticas dan licencia para convertirse quizá en la más activista del mundo. Más importante aquí, ha actuado como sustituto del legislativo en varias ocasiones, inyectando política

\footnotetext{
${ }^{4}$ Kramer (2000), por ejemplo, argumenta que la estructura descentralizada de partidos en Estados Unidos protege al federalismo estadounidense, de modo que las cortes no necesitan proteger este valor por medio de la doctrina. Levinson y Pildes (2006) sostienen que los estudios y la doctrina judicial sobre división de poderes en Estados Unidos deberían reconocer que las fuerzas principales en la política estadounidense son los partidos y no las ramas de gobierno.

${ }^{5}$ Ver Bushnell (1993, 201-248).
} 
en el sistema, manejando problemas muy complejos y policéntricos, y desarrollando una amplia concepción de los derechos constitucionales que utiliza para vigilar al poder ejecutivo. E1 litigio de la vivienda antes descrito es un ejemplo de esta estrategia. La sustitución del legislativo parece ser intrusiva y reñiría con la actual teoría constitucional estadounidense porque niega totalmente el concepto de una esfera legislativa independiente. Pero argumento que esta estrategia tiene sentido y ha sido productiva en las condiciones institucionales de Colombia. Debido a que el legislativo a menudo es incapaz de asumir las tareas básicas de proposición de políticas, manejo, control político y vigilancia del ejecutivo, la Corte ha tenido que desempeñar esas funciones, al menos periódicamente. Además, ha demostrado que es capaz de desarrollar muchas de las capacidades de recolección de información y de supervisión que usualmente se asocian con el legislativo. Por ejemplo, ha usado el mecanismo de reclamación individual, que da a los individuos fácil acceso a la Corte, para valorar problemas sociales importantes, y ha confiado en sus propias sesiones de estilo legislativo y en una red de aliados de la sociedad civil e instituciones del Estado para recoger información sobre las políticas y supervisar sus resultados. Por último, su popularidad, que sugiere un vínculo directo con el pueblo, y su capacidad para estimular la discusión y el compromiso de grupos de la sociedad civil en asuntos importantes, sugieren que no es tan antidemocrática como aduciría la teoría estándar.

E1 resto del artículo está organizado de la siguiente manera: en la sección I muestra que la labor académica existente está mal equipada para construir una teoría del rol judicial que sea apropiada para las nuevas democracias porque no empieza con el análisis de las instituciones políticas domésticas. La sección II explica el contexto colombiano, centrándose en la incoherencia de la política legislativa, mientras que la sección III describe y evalúa las estrategias fallidas y exitosas que ha usado la Corte colombiana en reacción a ese contexto. La sección IV sitúa la experiencia colombiana en una perspectiva comparativa, explica por qué el rol judicial que ha sido necesario en Colombia no ha sido adoptado por otras dos cortes fuertes, las cortes constitucionales húngara y surafricana, que actúan en contextos institucionales diferentes. En los años noventa, la Corte Constitucional húngara ("la Corte húngara") asumió un papel similar al de la Corte colombiana, pero sólo por breve tiempo: cuando el sistema de partidos mejoró en el período postcomunista, disminuyó la necesidad del extraordinario activismo judicial. Por su parte, la Corte Constitucional 
surafricana adoptó una posición más dialógica y deferente con las ramas políticas; la existencia de un solo partido dominante en vez de un conjunto incoherente de actores políticos permite explicar este rol. La sección $\mathrm{v}$ concluye argumentando que la evaluación comparativa de las instituciones políticas nos puede ayudar a imaginar el tipo de preguntas que nos debemos hacer cuando evaluamos la labor de una corte. También sugiero una teoría del rol judicial que puede funcionar donde los cuerpos legislativos funcionan mal, como en Colombia.

\section{TEORÍA CONSTITUCIONAL Y CORTES COMPARADAS}

Los académicos han dedicado pocos esfuerzos a la construcción de una teoría constitucional adecuada para analizar la labor de las cortes fuera de Estados Unidos. Aunque en varias disciplinas se han hecho abundantes trabajos sobre el fortalecimiento del poder judicial, la mayoría busca explicar las condiciones en que éste ocurre en vez de crear instrumentos para entender lo que deberían hacer las cortes en las nuevas democracias. Este vacío es sorprendente dada la obsesión de generaciones de estudiosos por construir teorías constitucionales para explicar, justificar y criticar la labor de la Corte Suprema de Estados Unidos. Infortunadamente, como explico, la extensa literatura estadounidense sobre el rol judicial es inadecuada para muchos países en desarrollo. $\mathrm{Y}$ aunque están surgiendo teorías del rol judicial en derecho constitucional comparado, éstas dan insuficiente atención al impacto de las diferencias en las instituciones políticas sobre lo que deberían hacer los jueces.

\section{A. LOS FUNDAMENTOS INSTITUCIONALES DE LA TEORÍA CONSTITUCIONAL ESTADOUNIDENSE NO SON APLICABLES EN EL MUNDO EN DESARROLLO}

Desde el siglo XIX, los profesores del Derecho estadounidense han enfrentado la pregunta normativa del rol de la Corte Suprema en nuestra democracia. Este abundante cúmulo de trabajos, aunque diverso, se basa en un conjunto de supuestos compartido sobre el proceso político. La idea central es que el papel adecuado de la judicatura debe ser limitado, debido al papel independiente que los cuerpos legislativos cumplen más apropiadamente ${ }^{6}$. Estos estudiosos no concuerdan en

\footnotetext{
${ }^{6}$ Haciendo eco a la literatura, aquí me ocupo de los cuerpos legislativos. Por supuesto, en sistemas presidenciales los presidentes son elegidos directamente y pueden tener derecho a un rol judicial limitado. Pero el argumento de la deferencia judicial hacia los presidentes parece más débil que el de la deferencia hacia los cuerpos legislativos que funcionan bien, porque el presidente no representa la misma variedad de intereses y porque la idea de constitucionalismo parece antitética al gobierno de una persona, democráticamente elegida o no. Por ejemplo,
} 
el tamaño relativo de estos dos papeles, pero en general concuerdan en el punto básico de que el rol judicial debe ser limitado porque hay tareas mejor adaptadas al legislativo debido a su mayor legitimidad, su cercanía al pueblo o sus ventajas institucionales.

Pero este punto fundamental, que sirve de base a la teoría constitucional, falla en muchos países en desarrollo. Como muestro más adelante, tiende a fallar por tres razones básicas: porque la separación entre política ordinaria y constitucional no es clara, porque no existe una cultura constitucional difundida y, sobre todo, porque los cuerpos legislativos a menudo no funcionan como entidades coherentes. Donde existen estas tres condiciones (como suele suceder en el mundo en desarrollo), es difícil que la deferencia hacia el rol legislativo sea la base de la teoría constitucional. Debemos encontrar otro fundamento para limitar el poder judicial.

Mi objetivo aquí no es revisar de manera exhaustiva esta abundante literatura; tan sólo busco señalar que los factores básicos que sirven de base en la construcción de los roles judicial y legislativo en el derecho constitucional estadounidense son problemáticos en muchas otras democracias. Mi objetivo tampoco es criticar la teoría constitucional: algunos de los autores que comento más adelante limitan explícitamente su análisis a contextos políticos particulares ${ }^{7}$. Sólo señalo que estas teorías ofrecen poca guía cuando no se cumplen ciertos supuestos políticos y, por tanto, que en estos contextos se necesitan instrumentos teóricos diferentes.

\section{La linea entre politica ordinaria y constitucional no es clara}

Un supuesto central en el pensamiento constitucional estadounidense es que los asuntos constitucionales son un subconjunto relativamente pequeño de los asuntos políticos. Este supuesto se basa en una historia institucional del rol judicial: al legislativo se le da amplio espacio para hacer política ordinaria, y las cortes sólo deben intervenir cuando sobrepasa ciertos límites, como cuando ataca al sistema político o

O’Donnell (1999, 40-41) señala que el control de la discreción del ejecutivo está cerca del núcleo del constitucionalismo. Los presidentes también tienden a ser disfuncionales en el mundo en desarrollo, por las mismas razones que los legislativos tienen problemas; por ejemplo, donde los sistemas de partidos no están bien institucionalizados, algunos "intrusos" ganan la elección a la presidencia con plataformas vagas y luego aplican políticas contrarias a las que prometieron, sin vigilancia del órgano legislativo u otras instituciones (ver Mainwaring y Scully, 1996 y Stoke, 2001).

7 Para Ealdron (2006, 1360), por ejemplo, la existencia de "instituciones democráticas en un orden que funciona razonablemente bien, incluido un cuerpo legislativo representativo", es un prerrequisito de su ataque al poder judicial.

Revista de Economía Institucional, vol. I3, N. ${ }^{\circ} 24$, Primer semestre/2oil, pp. I3-83 
anula negociaciones fundamentales ${ }^{8}$. En otras palabras, supone que la Constitución establece marcos de gobernanza y saca de la mesa algunos temas fundamentales; lo que no significa que los traslade a la política común.

Este supuesto no encaja bien en las constituciones más nuevas, en particular en las de países en desarrollo. Como señaló Kim Lane Scheppele, en esos países se tiende a adoptar constituciones "extensas", con grandes cantidades de material-disposiciones socioeconómicas, derechos de grupos, etc.- que en Estados Unidos normalmente se dejan a la legislación ordinaria9. También se tiende a regular rubros con gran detall $\mathrm{e}^{10}$. Y a menudo se construye expresa o implícitamente una jerarquía de normas constitucionales, con formulaciones vagas, en particular sobre la dignidad humana, que actúan como supernormas en el sistema ${ }^{11}$. Como resultado de la interacción de estas tres características es casi imposible imaginar un asunto que no plantee problemas constitucionales potenciales.

Los estudiosos tienden a condenar este fenómeno porque es extraño o poco recomendable, y sugieren que estos países se asfixiarán por exceso de derecho constitucional o que no entienden lo que se supone debe hacer una constitución ${ }^{12}$. Pero hay lógica en la extensión de muchas constituciones del mundo en desarrollo y post-autoritario. Las constituciones de los países en desarrollo son por necesidad documentos transformadores; ninguno de esos países desea quedarse como está ${ }^{13}$. Puesto que se considera en general que el orden político

${ }^{8}$ Holmes $(1995,134)$ argumenta que el derecho constitucional es antitético a la política democrática mayoritaria. Ackerman (1991, 6-7) contrasta la "legislación ordinaria", decisiones que el gobierno toma "diariamente", con la "legislación superior", que ocurre "rara vez", y argumenta que las cortes están encargadas de impedir que los políticos "exageren su poder" derogando actos previos de legislación superior. Ely $(1980,87)$ dice: "de hecho, la selección y adaptación de valores sustantivos se deja casi totalmente al proceso político", y que la Constitución se ocupa de "asegurar una amplia participación en los procesos [...] de gobierno".

9 Ver Scheppele (2005, 37-38): "Las nuevas constituciones dan respuesta a preguntas que, en democracias constitucionales más antiguas, plantea la legislación y no la constitución".

${ }^{10}$ Ibíd., 38. Rosenn $(1990,777)$ comenta la extensión y el detalle de la Constitución post-autoritaria de Brasil, que "contiene 245 artículos y 70 disposiciones transitorias".

${ }^{11}$ Dupré (2003) muestra que la judicatura húngara importó y usó la supernorma de dignidad del derecho constitucional alemán. Klug (2000, 164-165) indica que la dignidad es una supernorma potencial en el derecho constitucional sudafricano. Uprimny (2006, 128-131) describe la idea de "Estado social de derecho" como una supernorma potencial en el derecho constitucional colombiano.

12 Por ejemplo, Rosenn (1990) critica la Constitución brasileña por ser muy extensa y farragosa; Kugler y Rosenthal (2005, 75-76) exponen un argumento similar sobre Colombia.

${ }^{13}$ Sunstein $(2001,68)$ define las constituciones transformadoras como aquellas 
ordinario es muy defectuoso (por razones que discuto en detalle más adelante), los redactores sienten la necesidad de transformar no sólo la sociedad y la economía sino también la política ${ }^{14}$. Y éste es el problema: si hoy no se puede confiar en los procesos políticos ordinarios, no hay razones para creer que puedan ayudar a lograr un mejor orden social o económico. La constitucionalización extensa es entonces una señal de que la política ordinaria no solucionará los problemas de un país ${ }^{15}$. De ahí el gran número de cuerpos (cortes, defensores del pueblo, comisiones de derechos humanos, etc.) a los que se da poder de control constitucional en muchas constituciones nuevas ${ }^{16}$. La extensión no necesariamente da a las cortes constitucionales un mandato para intervenir en remplazo de instituciones ordinarias débiles; puede ser, como muchos argumentan en Estados Unidos ${ }^{17}$, que los mejores intérpretes del texto constitucional sean las instituciones elegidas y no la Corte. Pero ofrecen al menos la posibilidad de una vigorosa intervención judicial.

\section{La cultura constitucional es débil o inexistente}

Cualquier caso de interpretación no judicial de textos constitucionales es mucho más débil donde es improbable que los actores políticos se atengan a la Constitución. Y aquí la teoría constitucional de Estados Unidos tampoco es muy útil para los países en desarrollo. La vertiente reciente más importante en teoría constitucional estadounidense, el constitucionalismo popular, sugiere que en Estados Unidos existe y ha existido siempre una ferviente cultura de interpretación constitucional fuera de las cortes, dentro y fuera de las instituciones elegidas ${ }^{18}$. $\mathrm{Y}$ aduce que esta tradición sería más ferviente si la Corte Suprema no intentara monopolizar la interpretación constitucional mediante reclamos de supremacía judicial ${ }^{19}$. Puesto que instituciones elegidas como el Congreso también se atienen a valores constitucionales y

que "no intentan preservar un pasado idealizado sino señalar el camino hacia un futuro ideal".

${ }^{14}$ En la sección I.A.3 se tratan las disfunciones del comportamiento legislativo.

${ }^{15}$ Ver Scheppele $(2005,37-38)$.

${ }^{16}$ Elmendorf (2007) describe el ascenso de instituciones de control diferentes de las cortes, como las defensorías del pueblo y los consejos de derechos humanos. Pegram (2008) teoriza sobre el papel de los defensores del pueblo en América Latina.

${ }_{17}$ Ver el texto que acompaña a las notas 18-22.

${ }^{18}$ Ver, p. ej., Kramer (2004), Tushnet (1999) y Whittington (2002).

19 Tushnet (1999, 57-65) argumenta que la pretensión de los jueces de ser intérpretes supremos de la Constitución y su activismo en la interpretación constitucional induce un "vuelo judicial" que reduce los incentivos de otros actores para tomar en serio la Constitución. 
tienen más legitimidad democrática, deberían asumir algunas de las funciones de revisión constitucional de la rama judicial ${ }^{20}$.

Hay evidencia empírica de que, en Estados Unidos, el Congreso sí se preocupa por la Constitución; por ejemplo, los comités debaten de modo rutinario asuntos constitucionales, e históricamente el legislativo y el ejecutivo han decidido muchos asuntos de derecho constitucional sin ayuda de las cortes ${ }^{21}$. Además, actores no elegidos, como grupos de la sociedad civil, medios de comunicación y el público en general, exponen muchos de sus argumentos en términos constitucionales ${ }^{22}$. Y es plausible (aunque discutible) que estos actores tomarían aún más en serio la interpretación constitucional si las cortes no pretendieran monopolizar esa tarea.

Pero es erróneo pensar que en la mayoría de los países, aparte de Estados Unidos, los actores políticos y los ciudadanos comunes expongan sus opiniones políticas a la luz de su constitución, sin importar que sus cortes sean o no activistas, porque no existe la robusta cultura constitucional que parece haber existido en Estados Unidos durante toda su historia. En gran parte del mundo en desarrollo no es raro que las élites políticas y la gente común desprecien o ignoren la Constitución, en vez de tomarla en serio ${ }^{23}$. Según los estudiosos, las razones para ello provienen de la falta de experiencia constitucional o, aún peor, de una larga experiencia de violación de la Constitución ${ }^{24}$. En América Latina, por ejemplo, existe una larga historia de excelsos textos constitucionales flagrantemente ignorados por las élites políti-

${ }^{20}$ Ver ibíd., donde se defiende el constitucionalismo popular con argumentos democráticos. Kramer $(2004,252-253)$ argumenta en favor de una teoría de la interpretación constitucional repartida entre jurisdicciones, en vez de la supremacía judicial, que daría al Congreso y al presidente una autoridad independiente sobre la interpretación constitucional. Whittington (2002, 848-849) propone reconsiderar la deferencia que se debe a las decisiones constitucionales de las cortes.

${ }^{21}$ Whittington et al. $(2006,396)$, en un estudio empírico, encuentran que el Congreso trata asuntos constitucionales rutinariamente; Whittington (1999) describe las maneras de ajustar el significado de ciertos asuntos constitucionales por medio de luchas políticas.

22 Tushnet (1999, 135-141) muestra de qué maneras los ciudadanos han desarrollado sus propios significados constitucionales en reacción a importantes decisiones de la Corte Suprema de Estados Unidos.

${ }^{23}$ Okoth (1993) señala que la mayoría de los países africanos adoptaron constituciones pero las élites políticas no acatan los principios constitucionales. Schor $(2006,5)$ argumenta que en América Latina los ciudadanos apoyan las elecciones, pero que esto no se ha traducido en un "apoyo a los límites constitucionales del poder", y que las élites políticas saben que las normas constitucionales "se pueden ignorar o cambiar en medio de una disputa”.

${ }_{24}$ Okoth $(1993,66)$ afirma que en África las constituciones han fallado para "regular el ejercicio de poder" y que rara vez son valoradas como algo más que "retórica". Schor $(2005,29)$ señala que, en términos de comportamiento, "las constituciones [de América Latina] han sido flexibles y no rígidas”. 
cas, y en muchos países la Constitución es reformada o reescrita por completo con alarmante frecuencia ${ }^{25}$. Como señala Miguel Schor, "Hay pocas razones para que los ciudadanos se movilicen en nombre de reglas que quienes están en el poder pueden modificar fácilmente" ${ }^{26}$. Así, mientras que los politólogos de Estados Unidos asumen que la Constitución es una parte importante del pegante que mantiene unida a la sociedad, los teóricos políticos y sociales que trabajan en el extranjero entienden que así sea deseable inculcar una cultura constitucional robusta, alcanzarla es un logro raro $^{27}$.

Pero si es cierto que es improbable que los ciudadanos y los actores políticos de gran parte del mundo en desarrollo tomen en serio sus constituciones, parece imprudente darles mucha autoridad para interpretar la Constitución porque no hay razones para pensar que harán mucho esfuerzo para entender el proyecto transformador incrustado en ella. En sí mismo, éste no es un argumento afirmativo en favor de la interpretación judicial de la Constitución -las cortes pueden o no atenerse mejor a los valores constitucionales que los políticos- pero se puede pensar que si la cultura constitucional llega a existir en una nueva democracia, se apoyará en su corte constitucional. Después de todo, la razón de ser de estos actores es la interpretación constitucional (suponiendo que pertenecen a cortes especializadas), y suelen ser parte de redes transnacionales de jueces y estudiosos que toman en serio el derecho constitucional ${ }^{28}$.

Las relaciones que postula la literatura constitucionalista popular estándar parecen ser exactamente opuestas en Colombia, por ejemplo. Esa literatura postula que en Estados Unidos los reclamos de supremacía judicial de la Corte Suprema son en general un obstáculo para que el pueblo desarrolle el constitucionalismo, y considera que el Congreso es el vocero adecuado de las opiniones populares sobre la Constitución ${ }^{29}$. En Colombia la Corte Constitucional parece hacer mejor la tarea de reflejar las opiniones populares de transformación constitucional; en cambio, la disposición y la capacidad del cuerpo legislativo para efectuar

\footnotetext{
${ }^{25}$ Borón $(1993,339)$, por ejemplo, hace referencia a la "proliferación de constituciones y la debilidad del constitucionalismo" en la región.

${ }^{26}$ Schor (2006, 25).

27 Alemania nos muestra cuán difícil e históricamente limitado puede ser la construcción de lo que Jürgen Habermas llama "patriotismo constitucional". Los ciudadanos alemanes desarrollaron un profundo apego a su constitución, pero sólo al cabo de la Segunda Guerra Mundial, que los convenció de la necesidad de adherir a principios fundamentales de derechos humanos (como la dignidad humana) y de los problemas de un nacionalismo de base étnica (ver Müller, 2007, 15-45).

${ }^{28}$ Slaughter $(1994,99)$ examina este tipo de redes judiciales transnacionales.

${ }^{29}$ Ver, p. ej., Kramer (2004) y Tushnet (1999).
} 
la transformación constitucional son muy limitadas. La extraordinaria popularidad de la Corte colombiana -en general más popular que el Congreso o el ejecutivo- respalda la idea de que es el principal portador de la visión de transformación constitucional ${ }^{30}$.

\section{Las instituciones representativas son altamente disfuncionales}

A un nivel más básico, los reclamos de deferencia judicial hacia las instituciones legislativas -si los asuntos se enmarcan o no en términos constitucionales- se basan en ideas acerca de la legitimidad democrática y la mayor capacidad de la rama legislativa para recoger información y diseñar políticas. Durante mucho tiempo la teoría constitucional estadounidense ha considerado que las credenciales democráticas del legislativo son una razón para limitar el poder judicial ${ }^{31}$. De hecho, esta noción es la base de "la dificultad contra-mayoritaria" de Bickel: la revisión judicial puede ser "antidemocrática" porque "se opone a la voluntad de los representantes del pueblo real aquí y ahora, ejerce el control, no en nombre de la mayoría predominante sino en su contra" ${ }^{32}$. Otra línea de pensamiento subraya la capacidad institucional potencialmente superior de las cortes para formular políticas y vigilar al poder ejecutivo ${ }^{33}$. Los trabajos empíricos encuentran que el Congreso de Estados Unidos tiene gran capacidad para recoger y evaluar información, principalmente a través del sistema de comités, lo cual le permite formular complejas iniciativas de política y evaluar y controlar el desempeño del ejecutivo y de otros actores ${ }^{34}$.

${ }^{30}$ Faundez $(2005,758)$ anota que la Corte registra un grado de aceptación superior al 50\%, algo inusual para las cortes e instituciones políticas de América Latina.

${ }^{31}$ Ver Bickel (1986), Ely (1980), Tushnet (1999) y Thayer (1893, 129). Waldron $(2006,1406)$ argumenta que los procedimientos legislativos son la mejor manera de "tratar, en forma responsable y deliberativa, los difíciles y complejos problemas que generan los desacuerdos sobre derechos".

32 Bickel (1986, 17).

${ }^{33}$ Vermeule (2006, 230), por razones institucionales, argumenta que las cortes son mejores para actualizar el texto constitucional, pero Bickel $(1978,175)$ sostiene que suelen ser peores para diseñar políticas porque el proceso jurídico es altamente limitado por principios. Rosenberg (1991) resume los argumentos sobre las deficiencias de capacidad judicial. Devins y Meese $(2005,327)$ observan que las cortes estadounidenses, a diferencia de los cuerpos legislativos, usualmente no realizan audiencias. Fuller $(1978,394-395)$ dice que las cortes son poco adecuadas para tratar problemas complejos y policéntricos por restricciones de su capacidad institucional.

${ }_{34}$ Cox y McCubbins (1993) argumentan que Estados Unidos tiene partidos fuertes y que estos ayudan a coordinar tareas en la Cámara de Representantes. Krehbiel (1991) señala que gran parte de las tareas cotidianas de recolección de información y de política de los cuerpos legislativos se realizan en comités. McCubbins et al. $(1989,431)$ afirman que el Congreso usa provechosamente sus comités para controlar la acción de agencia. 
Los argumentos de legitimidad democrática y de capacidad son problemáticos en el mundo en desarrollo. A veces, la legitimidad democrática está limitada por el fraude electoral abierto, que asedia a muchas democracias nominales y debilita el vínculo entre el legislador y el pueblo ${ }^{35}$. Muchos cuerpos legislativos del mundo en desarrollo tienen pocos recursos, lo que reduce su eficacia como diseñadores de política y contrapesos del ejecutivo ${ }^{36}$. Pero la principal fuente de problemas de los cuerpos legislativos que funcionan mal es el sistema de partidos. Como dicen Daryl Levinson y Rick Pildes, el sistema de partidos es la clave para entender el comportamiento del legislativo ${ }^{37}$. Los académicos familiarizados con el comportamiento político estadounidense están acostumbrados a un sistema con dos partidos fuertes, que poseen una identidad ideológica más o menos clara y una disciplina relativamente alta (es decir, la mayoría de sus miembros tienden a votar en conjunto la mayoría de las veces). Estos dos partidos compiten por votos y tienden a rotarse en el poder con bastante regularidad.

Pero la semblanza de los sistemas de partidos en el mundo en desarrollo es a menudo muy desoladora, pues los partidos políticos suelen estar plagados de dos tipos de disfunciones. En el primer tipo, por ejemplo, hoy en Suráfrica y antes en India y México, un partido dominante que controla el sistema rara vez pierde su estatus mayoritario. En contra de lo que se podría esperar, en estos sistemas parecen ser posibles cortes constitucionales fuertes e independientes (aunque bastante raras), como muestran los ejemplos de India y Suráfrica ${ }^{38}$. En parte, porque los partidos dominantes suelen redactar la Constitución y, por tanto, creen en ella. Entonces toleran e incluso acogen el trabajo de las cortes comprometidas con el mismo proyecto general de realización constitucional. Además, por necesidad, esos partidos no son monolíticos sino que tienden a incluir una amplia variedad de intereses dentro del redil ${ }^{39}$.

Además, dichos sistemas producen graves patologías para el desarrollo democrático y, de hecho, en términos de adherencia a derechos civiles y políticos, "ocupan una posición económica intermedia entre sistemas de partidos competitivos y estables, por una parte, y sistemas

${ }^{35}$ Schedler $(2002,36)$ lista métodos y ejemplos de fraude electoral.

${ }^{36}$ Morgenstern (2002) observa que los cuerpos legislativos latinoamericanos tienen menos recursos y comités más débiles que el Congreso de Estados Unidos.

37 Ver Levinson y Pildes (2006).

38 Baar $(1990,140)$ señala que la Corte india es muy activa a pesar del contexto de un partido dominante. Roux (2008) comenta que la Corte surafricana ha sido bastante activa e independiente a pesar del contexto político. Widner (2001) documenta los intentos parcialmente exitosos de los jueces de Tanzania para construir poder e independencia judiciales en un Estado de partido único.

${ }^{39}$ Ver Friedman $(1999,102)$. 
autoritarios de gobierno, por la otra" ${ }^{40}$. Esto crea una alta probabilidad de que ciertos intereses externos al partido sean excluidos permanentemente del poder ${ }^{41}$. Igualmente importante, es improbable que la competencia entre facciones del partido replique perfectamente el buen funcionamiento de un sistema de competencia entre partidos. Incluso intereses y voces internos al partido pueden tender a quedar excluidos del poder durante largos períodos ${ }^{42}$. Así, es posible que en estos sistemas el cuerpo legislativo sea capaz (el partido dominante da cierto nivel de coherencia), pero carezca de legitimidad democrática. En este tipo de sistemas, una corte puede ser involucrada en el proceso de representación-reforzamiento que John Hart Ely describe en Democracy and Distrust ${ }^{43}$, pero más intensamente debido a las graves disfunciones ocasionadas por el sistema de partido único.

Existe un problema más grave donde los partidos políticos son sumamente débiles, lo que convierte al legislativo en un cuerpo incoherente. El concepto clave es el que Mainwaring y Scully llaman "institucionalización del sistema de partidos", que mide la profundidad de las raíces que los partidos tienen en la sociedad ${ }^{44}$. Mientras que las democracias desarrolladas casi siempre tienen sistemas de partidos institucionalizados, las democracias más nuevas a menudo sufren de una falta de institucionalización de los partidos políticos ${ }^{45}$. En sistemas no institucionalizados los partidos tienden a tener plataformas ideológicas laxas o inexistentes; son ante todo vehículos de conveniencia de candidatos individuales que buscan cargos, no agrupaciones de individuos con puntos de vista políticos similares ${ }^{46}$. Estos partidos también carecen de vínculos con grupos de la sociedad civil (sindicatos de trabadores, gremios de empresarios, grupos de interés, etc. ${ }^{47}$. Internamente, suelen ser indisciplinados y sufren deserciones de políticos con cargos oficiales (lo que los latinoamericanos llaman “cambio de camiseta") ${ }^{48}$. Los sistemas en conjunto son volátiles: los partidos adquieren protagonismo y luego se desintegran en pocos

${ }^{40}$ Simkins $(1999,57)$.

${ }^{41}$ Ver Giliomee y Simkins (1999a, 40-41).

42 Ver Friedman $(1999,102)$.

${ }_{43}$ Ely $(1980,102)$ describe la función judicial de asegurar "que todos puedan intervenir".

${ }^{44}$ Ver Mainwaring y Scully (1996a, 1).

45 "En los regímenes de transición, los partidos políticos y los sistemas de partidos a menudo carecen de institucionalización" (Skach, 2005, 65).

${ }^{46}$ Mainwaring y Scully $(1996 a, 5)$ observan que en los sistemas de partidos no institucionalizados los partidos cambian con frecuencia de posición ideológica.

47 Ibíd.

48 Ibíd., 16; ver Conaghan $(1994,273)$ sobre la influencia del cambio de camiseta en Ecuador. 
años; los partidos más viejos mueren continuamente, y constantemente surgen partidos nuevos ${ }^{49}$. Por último, estos sistemas suelen ser fragmentados; tiende a haber muchos partidos, muchos de ellos tan pequeños que se los llama "partidos taxi” porque sus convenciones nacionales caben en un taxi ${ }^{50}$.

Es posible que los sistemas de partidos no institucionalizados produzcan cuerpos legislativos con bajos niveles de legitimidad democrática y de capacidad institucional. Donde los partidos carecen de plataformas ideológicas claras y no duran mucho tiempo, los votantes no pueden usar la identificación de partido como instrumento para evaluar los puntos de vista de los posibles legisladores. Pero el rótulo de partido es un atajo necesario para los votantes: sin él, no pueden tomar una decisión informada ${ }^{51}$. Y donde el significado ideológico del rótulo de partido es maleable, los votantes no obtendrán lo que creen que obtendrán aunque confíen en el rótulo de partido ${ }^{52}$. Por último, en un sistema de partidos débil la dinámica interna del legislativo desfavorece los resultados democráticamente aceptables. Las coaliciones son inestables, y se forman para repartir favores personales a legisladores individuales, no porque se llegue a un compromiso político coherente ${ }^{53}$. En ese cuerpo legislativo es improbable que los resultados representen las opiniones de una mayoría clara y, de hecho, de un grupo social grande e identificable ${ }^{54}$.

${ }^{49}$ Ver Mainwaring y Scully (1996a, 13-15).

50 Gamarra (1996, 412) hace referencia a los "partidos taxi" en Bolivia.

51 "Donde un sistema de partidos es menos institucionalizado, es difícil establecer la responsabilidad. La mayoría de los ciudadanos no puede evaluar vastos números de políticos individuales" (Mainwaring y Scully, 1996a, 25).

${ }^{52}$ Ver ibíd., donde se observa que en dichos sistemas los políticos no "están comprometidos con las plataformas del partido" y "toman decisiones políticas que tienden a ser de corta vida y erráticas". Estos problemas afligen a los presidentes y a los legisladores. Los políticos "intrusos" que han ganado la presidencia en América Latina a menudo han tomado medidas contrarias a sus (vagas) plataformas (ver ibíd., 22-23). Ver también Stoke (2001), quien muestra que Alberto Fujimori en Perú y Carlos Menem en Argentina impusieron duras medidas neoliberales después de hacer campaña como populistas.

${ }_{53}$ Ver Skach (2005, 65-66).

${ }^{54}$ Algunos académicos sostienen que incluso donde el legislativo no funciona como un cuerpo particularmente democrático, las cortes deberían tenerle deferencia porque el público lo ve como un diseñador de políticas legítimo (ver Eskridge y Ferejohn, 2006, 325). Pero este argumento también tiende a fallar en países con un sistema de partidos débil: los cuerpos legislativos de esos países tienen graves problemas de legitimidad porque funcionan muy mal $y$ porque los intereses personalistas de los legisladores fomentan la corrupción. Mainwaring et al. (2006, 17, tabla 1.3) muestran que la confianza pública en los partidos y en el poder legislativo es muy baja en la región andina de América Latina, la cual exhibe en general sistemas de partidos no institucionalizados. Scheppele (2005, 34) observa que "la legitimidad de las nuevas instituciones elegidas no es muy alta en el mundo post-soviético". 
Además, en sistemas de partidos no institucionalizados la capacidad de los cuerpos legislativos es en general baja; usualmente tienen débiles sistemas de comités y no tienen capacidad para formular iniciativas de política importantes. Esto se debe a que los líderes de los partidos fuertes con intereses de largo plazo tienen incentivos y capacidad para acumular poder legislativo ${ }^{55}$. Los legisladores individuales en general no tienen ese interés; su interés principal consiste en obtener beneficios particulares (dinero, empleos, etc.) para ellos y sus aliados, en vez de hacer política amplia o supervisar al ejecutivo ${ }^{56}$. En la política moderna las plataformas de partido y los grupos de expertos partidistas son una fuente importante de ideas política serias ${ }^{57}$. Por tanto, donde los partidos son débiles y las plataformas vagas, entran al sistema menos ideas políticas importantes. La alta fragmentación y la baja disciplina de partido significan que estos cuerpos legislativos tienen incluso dificultades para aprobar leyes que gozan de mucho respaldo $^{58}$. Por último, la gran inestabilidad de las coaliciones y de los resultados electorales ayuda a asegurar que los legisladores sean incapaces de acumular la pericia necesaria para manejar iniciativas políticas ${ }^{59}$.

En suma, la teoría constitucional estadounidense se basa en concepciones del contexto institucional que no se aplican en buena parte del mundo en desarrollo. La división estándar entre el rol legislativo y el rol judicial tiene poco sentido donde las constituciones son extensas porque el constitucionalismo es un proyecto altamente transformador, los políticos tienen poco interés en el desarrollo constitucional y el cuerpo legislativo está cerca de ser disfuncional. Se deben encontrar otras maneras de evaluar la acción judicial.

55 Cox y McCubbins (1993, 275-278) afirman que el poder de las legislaturas estadounidenses es resultado de la fortaleza de los partidos. Deberíamos modificar un poco esta afirmación: los partidos fuertes pueden no crear sistemas de comités bien desarrollados porque, como en algunos sistemas parlamentarios (como el del Reino Unido), los dirigentes de los partidos centralizan la pericia política en el ejecutivo (Hibbing, 2002, 34-35). En cambio, donde los partidos no son institucionalizados, las bolsas de pericia política no existen en ninguna parte del sistema.

${ }^{56}$ Cox y Morgenstern (2002, 454) explican que en los sistemas de partidos no institucionalizados deberíamos esperar que los legisladores exijan retribuciones individuales. Mainwaring y Scully $(1996,27)$ sostienen que la corrupción es mucho más común en los sistemas de partidos no institucionalizados.

57 Dieter et al. (1994) encuentran que en Europa las ideas políticas más importantes provienen de las plataformas de los partidos.

${ }_{58}$ Mainwaring y Scully $(1996,26)$ sostienen que los sistemas de partidos no institucionalizados dificultan la aprobación de las leyes debido a problemas de disciplina y fragmentación de los partidos.

59 Hibbing (2002, 30-34) señala que la alta rotación hace más difícil que los legisladores individuales adquieran pericia. 


\section{B. EL DERECHO CONSTITUCIONAL COMPARADO NO SE APOYA EN LOS FUNDAMENTOS INSTITUCIONALES}

La teoría constitucional estadounidense no es útil para evaluar la labor de las cortes de los países en desarrollo porque depende de supuestos sobre las instituciones, en particular sobre el comportamiento del cuerpo legislativo, que no se cumplen en muchos de esos países. E1 campo emergente -y laxamente definido- del derecho constitucional comparado no se basa en fundamentos institucionales. Argumento que este enfoque es un error: el campo estaría mejor situado si se basara en el análisis comparado de las instituciones políticas.

Como indica Mark Tushnet, los estudios existentes sobre derecho constitucional comparado tienden a ser de dos tipos, ninguno de los cuales parece bastante adecuado como base de la teoría constitucional comparada. En el primer tipo, que Tushnet llama "expresivismo", el supuesto básico es que la doctrina constitucional está ligada estrechamente a las tradiciones y la cultura de un país, y refleja su rica textura ${ }^{60}$. Se considera que la forma en que las cortes deben responder a los problemas es una respuesta a valores culturales y tradiciones históricas profundamente arraigadas. $\mathrm{El}$ problema de este enfoque es que hace muy difícil cualquier comparación estructurada entre países; la jurisprudencia de cada país se basa en factores históricos únicos y no en factores que pueden variar de manera previsible entre países. La teorización es entonces casi imposible, e incluso es difícil evaluar o criticar la labor de una corte porque muchos aspectos del trabajo judicial se podrían justificar usando algún aspecto de la cultura o las tradiciones del país.

El otro enfoque, que Tushnet llama "funcionalismo" ${ }^{61}$, considera que el derecho constitucional migra fácilmente entre fronteras nacionales. Los funcionalistas empiezan intentando explicar cómo abordan grupos de países sus problemas comunes, y tienden a encontrar similitudes entre sistemas. Un ejemplo reciente del debate funcionalista es la literatura que compara el cumplimiento judicial de

\footnotetext{
${ }^{60}$ Tushnet (1999a, 1261-1285). Tushnet también discute y defiende un tercer enfoque llamado "bricolage", que consiste en tomar en préstamo trozos y piezas de doctrina en forma oportunista (ibíd., 1287-1305). El bricolage depende de una teoría acerca de cuándo y cómo es apropiado el préstamo doctrinal; dicho enfoque se beneficiaría de una fundamentación en el análisis comparado de las instituciones políticas.

${ }^{61}$ Ibíd. (1238-1269). En cierta forma, el debate entre funcionalismo y expresivismo guarda correspondencia con un debate fundamental en derecho comparado entre quienes piensan que el derecho es (y debería ser) fácilmente trasplantado entre sistemas y quienes consideran que no es trasplantable y está enraizado en aspectos fundamentales de la historia y la cultura de un país (ver Watson, 1993; Zweigert, 1998, y Rosenkrantz, 2003).
} 
los DESC. Esta literatura es diversa y de muy alta calidad; en contra de escritos anteriores de académicos de Estados Unidos, una de sus principales conclusiones es que hay una manera plausible de hacer cumplir estos derechos. A este enfoque lo podríamos llamar modelo dialógico. Conforme a este modelo, que se inspira en el famoso caso Government of the Republic of South Africa v. Grootboom ${ }^{62}$, las cortes intentan dar contenido a los derechos, pero de una manera que guarda la deferencia debida a la pericia y la legitimidad democrática de las

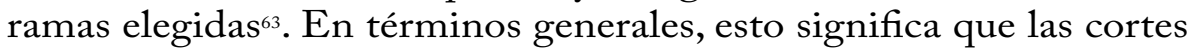
dicen a las otras ramas que se ha infringido un derecho socioeconómico y les dan una idea de por qué se ha infringido, pero luego se deja el plan para remediar la violación a la discreción y la pericia de las ramas elegidas. Este enfoque intenta hacer efectivos los DESC al tiempo que mantiene a raya las preocupaciones por la legitimidad y la capacidad judicial ${ }^{64}$.

La literatura sobre el caso Grootboom destaca la importancia de un instrumento doctrinal potencialmente importante para el cumplimiento de los DESC. Pero es un instrumento que depende del contexto político, un punto que no se aprecia plenamente en los trabajos existentes. Como explico en más detalle en la sección IV, la estrategia dialógica fue creada en Suráfrica, un país gobernado por un partido dominante coherente que normalmente comparte la visión constitucional básica con su corte constitucional ${ }^{65}$. Es discutible que este enfoque funcione en otros contextos institucionales. Por ejemplo, parece más o menos imposible que en un país con un sistema de partidos no institucionalizados se adopte el enfoque surafricano. El enfoque dialógico parece depender, como mínimo, de la presencia de actores políticos coherentes que estén interesados y sean capaces de desarrollar el derecho que la Corte identifica. Así, como veremos más adelante, la Corte colombiana adoptó una estrategia muy diferente para hacer cumplir los DESC; aunque interactúa a menudo con otras ramas, define y supervisa enérgicamente los detalles de política de una manera que sería anatema para la Corte Constitucional surafricana ${ }^{66}$.

62 2001(1) SA 46 (CC) (S. Afr.).

${ }^{63}$ Ver Tushnet (2008, 242-244), Dorf y Sabel (1998) y Sunstein (2001, 227235).

${ }^{64}$ Tushnet $(2008,264)$ argumenta que la revisión débil respeta el derecho, fundado en la teoría democrática, a que las mayorías prevalezcan cuando, al actuar a través de sus representantes, aprueban estatutos congruentes con interpretaciones razonables de la Constitución. Sunstein (2001, 237) argumenta que Grootboom obligó a cumplir los DESC "sin imponer una tensión indebida a la capacidad judicial".

${ }_{65}$ Ver sección IV.B.

${ }^{66}$ Ver sección III.C. 
El punto general aquí es que las teorías del rol judicial y de la estrategia judicial en derecho constitucional comparado se deberían apoyar aún más en el análisis comparado de las instituciones políticas. Este enfoque es realista porque reconoce que el rol judicial debe variar según las condiciones políticas; por ejemplo, un enfoque que funciona en un país con un sistema de partidos institucionalizados no necesariamente funciona en un país que carece de dicho sistema. También es factible porque no asume que la teoría constitucional comparada depende de las circunstancias históricas únicas de cada país, mientras que las diferencias notorias entre países dependen de variables de nivel medio susceptibles del análisis comparativo. En las siguientes secciones se empieza a construir dicha teoría explicando el contexto político colombiano y cómo ha respondido la Corte Constitucional colombiana a ese contexto ${ }^{67}$.

\section{LAS DISFUNCIONES DE LA DEMOCRACIA COLOMBIANA Y EL DISEÑO DE LA CORTE}

\section{A. El ConTexto Político: PARTidos débiles y un LEGISLATIVO CLAUDICANTE}

La Asamblea Constituyente de 1991 que creó a la Corte Constitucional fue convocada debido a la aguda violencia y a la sensación de que las instituciones políticas del país estaban fallando ${ }^{68}$. Buena parte de esta sensación de fracaso institucional provenía en últimas de los problemas del sistema de partidos.

Los dos partidos tradicionales, el Liberal y el Conservador, se formaron en el siglo XIX como grupos de notables que obtenían

${ }^{67} \mathrm{La}$ idea de que el rol judicial debe variar según el carácter de las instituciones políticas no es del todo ajena al pensamiento estadounidense sobre derecho público. Por ejemplo, Tushnet discute que una forma potencial de tratar las facultades de emergencia del ejecutivo en Estados Unidos y en otras partes sería forzar la aprobación del Congreso donde el poder está dividido pero realizar una revisión sustantiva independiente donde no lo está (Tushnet, 2007). Levinson y Pildes (2006) sugieren que esa doctrina judicial debería ser sensible al control partidista de las diversas ramas, en vez de aceptar simplemente que la división de poderes asegura la vigilancia del ejecutivo. Una diferencia entre mi enfoque y estas teorías es que en la labor comparativa las características de los sistemas políticos se pueden tratar como características estructurales (relativamente) constantes del sistema, y no como variables modificables como la composición partidista del legislativo, que pueden ser más fáciles de incorporar en la estrategia y la doctrina judiciales. Por ejemplo, como explico más adelante, la Corte colombiana ha tenido que tratar la incoherencia legislativa como una característica permanente del sistema, y así ha adoptado un papel muy activo en la política (ver la sección III).

${ }^{68}$ Ver Segura y Bejarano $(2004,219)$. 
votos manipulando redes de cacicazgo en gran parte rurales ${ }^{69}$. Inicialmente se dividieron por diferencias en temas ideológicos, en particular el federalismo y la religión y, más importante, por intensos odios personales y conflictos entre facciones ${ }^{70}$. Los rencores entre los dos partidos desataron una guerra civil esporádica pero sangrienta en los años cuarenta y cincuenta del siglo XX; la violencia terminó cuando las grandes facciones de ambos partidos establecieron un sistema de reparto del poder sumamente antidemocrático, el Frente Nacional $^{71}$. Durante el Frente Nacional, que duró desde 1958 hasta 1986, los dos partidos acordaron que los resultados de las elecciones fueran irrelevantes: se rotarían la presidencia, se dividirían los cargos del gabinete por partes iguales y la Corte Suprema se repartiría entre sus seguidores ${ }^{72}$. E1 pacto dio fin al conflicto entre los partidos, con un costo. Primero, los grupos sociales que quedaron fuera del cerrado sistema bipartidista recurrieron al conflicto armado; los movimientos insurgentes que han plagado al país crecieron rápidamente durante el período del Frente Nacional ${ }^{73}$. Segundo, cuando la competencia entre los partidos dejó de tener sentido, ganó importancia la competencia dentro de ellos. Perdieron la identidad ideológica coherente que poseían originalmente y se convirtieron en campos de batalla entre bandos rivales, organizados alrededor de individuos o familias notables, que luchaban por posiciones de predominio dentro de su propio partido ${ }^{74}$. Estas tendencias fueron alentadas por reglas electorales que eran consideradas "las más personalistas del mundo", daban a los jefes de partido poca autoridad sobre sus congresistas ${ }^{75} \mathrm{y}$ una excesiva representación a las zonas

${ }^{69}$ Palacio y Safford (2002, 151-156) describen los orígenes de los dos partidos entre 1831 y 1845 .

70 Además de la guerra civil en las décadas de 1940 y 1950, también hubo conflictos violentos entre los partidos o sus facciones entre 1859 y 1863 , en 1885 , y entre 1899 y 1902 (ibíd., 221-224, 245, 249-250).

${ }^{71}$ El pacto que creó el Frente Nacional en realidad se oponía a un dictador militar, el general Gustavo Rojas Pinilla, quien se tomó el poder prometiendo detener la violencia partidista pero fue ineficaz para lograr ese fin; además, sus políticas económicas representaban una forma suave de populismo que parecía amenazar los intereses de la élite (ibíd., 321-324).

${ }^{72}$ Para una explicación más completa de la guerra civil y los períodos del Frente Nacional, ver Bushnell (1993, 201-248).

${ }^{73}$ Ver ibíd. (244-248).

${ }^{74}$ Ver Pizarro $(2006,78)$.

75 Ver Carey y Shugart (1995). Más importante, los jefes de los partidos no controlaban la composición de sus listas: cualquier candidato podía promover su lista propia bajo cualquier rótulo de partido, pagando una suma pequeña. Además, las reglas permitían que los partidos tuvieran listas múltiples en la misma circunscripción, lo que alentaba la competencia dentro de ellos (Archer y Shugart, 1997, 110, 133-136). 
rurales, en particular en la Cámara de Representantes, lo que aumentó la importancia del clientelismo y redujo la importancia de la ideología partidista ${ }^{76}$.

La incoherencia del sistema de partidos creó graves problemas en el legislativo. Los legisladores tenían poco interés en promover a nivel nacional el nombre de su partido, y ganaban la elección principalmente canalizando partidas presupuestales y otros beneficios de pequeña escala hacia sus clientes ${ }^{77}$. Los dirigentes de los partidos se dividían en facciones y eran muy débiles para imponer disciplina en sus filas ${ }^{78}$. La disciplina de partido era baja: los partidos votaban por su facción y no como una unidad coherente ${ }^{79}$.

El Congreso colombiano era un ejemplo clásico de un cuerpo legislativo que, para usar la terminología de Levinson y Pildes, prefirió "abdicar" de su poder que "construir imperio" ${ }^{80}$. Las principales propuestas de política no se originaban en el legislativo; casi todo lo importante era diseñado por el presidente y su equipo de tecnócratas ${ }^{81}$. Además, el legislativo usualmente no se comprometía ideológicamente con los proyectos de ley del presidente ${ }^{82}$. Pero la aprobación de los proyectos no era fácil, porque se requería que el presidente diera a los legisladores suficientes fondos y otros beneficios personalistas para comprar su apoyo. Cuando los presidentes no podían cimentar una gran coalición de legisladores por falta de voluntad o de recursos, como solía suceder con medidas importantes de política, sus propuestas eran bloqueadas ${ }^{83}$. Por ello, usaban a menudo sus amplias facultades de emergencia para legislar directamente, pasando por alto al Congreso: entre 1970 y 1991, el país estuvo bajo algún tipo de estado de emergencia el $82 \%$ del tiempo ${ }^{84}$. Muchas veces, esos estados de emergencia no se declaraban para enfrentar crisis de seguridad auténticas sino para impulsar reformas económicas o sociales

76 Ibíd., 140.

77 "El Congreso colombiano está estructurado de un modo que le es intrínsecamente difícil abordar temas de política nacional pero que incentiva a sus miembros a cultivar intercambios personalistas basados en el cacicazgo" (ibíd., 111, 136-146).

${ }^{78}$ Ver ibíd. (134-136), donde se discute el problema del faccionalismo.

${ }^{79}$ Ver ibíd. (138), donde se observa que "la baja cohesión de los partidos" es un problema de la política colombiana.

${ }^{80}$ Levinson (2005).

${ }^{81}$ Archer y Shugart (1997, 144-146).

${ }^{82}$ Ibíd.

83 "E1 predominio potencial de la presidencia colombiana [...] seguía siendo más potencial que real porque el Congreso podía impedir que los presidentes usaran efectivamente sus facultades para ir más allá de lo que tolerarían los dirigentes de nivel medio de los partidos" (ibíd., 116).

${ }^{84}$ Uprimny (2004, 65, tabla 3). 
que estaban bloqueadas por el Congreso ${ }^{85}$. Asimismo, el Congreso delegaba en el ejecutivo la redacción de leyes sobre áreas de política prácticamente ilimitadas ${ }^{86}$.

Los problemas del Congreso eran entonces multifacéticos, pero en últimas tenían origen en la debilidad del sistema de partidos. En primer lugar, su aprobación de un proyecto poco decía de la compatibilidad con las fuerzas sociales reales del país, porque el Congreso poco las representaba, aparte de los caciques rurales. En segundo lugar, aunque el legislativo no podía proponer políticas o participar en debates de políticas importantes, podía bloquear y bloqueó muchas medidas importantes por razones dudosas (básicamente porque el presidente no podía comprar una coalición suficientemente grande). En esencia, era un punto de veto en la política colombiana, pero un punto de veto de baja calidad, porque era improbable que su reprobación de un proyecto representara una clara oposición social a ese proyecto ${ }^{87}$.

Este problema estructural básico de disfuncionalidad del legislativo se relacionaba con otros dos problemas, la amplitud del poder del ejecutivo para legislar por decreto y la claudicación del Congreso ante el ejecutivo en grandes áreas de política. Ambos mecanismos permitían que el presidente adoptara políticas sin cortapisas. Pero es necesario observar que estos dos problemas eran en cierto sentido mecanismos para enfrentar la debilidad estructural del legislativo colombiano, porque al menos permitían hacer política evitando el rol de bloqueo que normalmente ejercía el Congreso ${ }^{88}$. En el viejo régi-

${ }^{85}$ En la Constitución anterior había dos tipos distintos de emergencias, el estado de sitio para crisis de seguridad y el estado de emergencia económica para crisis económicas (Archer y Shugart, 1997, 126-130). Los presidentes usaban a menudo ambas facultades para poner fin al bloqueo del Congreso (ibíd., 127, 129).

${ }^{86}$ En ibíd. (117, 121-122) se dan ejemplos de delegación del legislativo al ejecutivo, y se anota que "la delegación de facultades extraordinarias al presidente [...] es simplemente una manera de satisfacer los intereses clientelistas [del Congreso] liberando a sus miembros de la carga de hacer política".

${ }^{87}$ George Tsebelis (2002) expone una teoría general de las instituciones políticas que se basa en el número de puntos de veto dentro de un sistema político y en los temas políticos que prefieren esos puntos de veto. Para nuestros propósitos lo que importa no es simplemente si una institución tiene la capacidad para vetar políticas sino también la calidad de ese punto de veto; el veto representa la desaprobación de algún grupo social importante que los teóricos democráticos deben tener en cuenta: ¿es aleatoria o se basa en la desaprobación de grupos que no son importantes desde el punto de vista de la teoría democrática?

${ }^{88}$ Mainwaring y Shugart (1997a, 394, 431-434 y tabla 11.6) observan que en América Latina hay una relación inversa entre las facultades constitucionales del presidente para emitir decretos y los niveles de apoyo cohesivo y disciplinado al presidente en el legislativo, porque las asambleas constituyentes intentan compensar los problemas de negociación que el presidente afronta en la legislatura. 
men, la mayoría de las medidas legislativas importantes se tomaban mediante algún tipo de decreto presidencial.

\section{B. UNA NUEVA CONSTITUCión Y UNA NUEVA CORTE CONSTITUCIONAL: RES- PUESTAS A LA DEBILIDAD INSTITUCIONAL}

La sensación de que las instituciones políticas no funcionaban bien dio gran impulso a la Asamblea Constituyente de 1991 ("la Asamblea"). Había un sentimiento general de que ciertas instituciones, en particular el Congreso, no representaban de manera adecuada a la sociedad y cumplían un papel meramente negativo de bloqueo dentro del sistema político ${ }^{89}$. De hecho, quienes propusieron la reforma decían que $\mathrm{Co}^{-}$ lombia era una "sociedad bloqueada", incapaz de reformarse a causa de la debilidad de sus instituciones políticas ${ }^{90}$. Correcta o erróneamente, los colombianos pusieron sus esperanzas en la reforma institucional como medio para aliviar los males - la guerra civil y el incumplimiento de la ley-que plagaban al país ${ }^{91}$. Los movimientos por una nueva constitución, que empezaron en los años ochenta, finalmente dieron fruto cuando la Corte Constitucional respaldó los resultados de la votación popular en favor de la convocatoria a la elección de una asamblea constituyente de 1990. La Asamblea, que se reunió entre febrero y julio de 1991, redactó una constitución totalmente nueva.

Aquí es innecesaria una descripción completa de la labor de esta asamblea, pero algunos detalles son importantes. Primero, políticamente marcó un raro momento en la historia colombiana en el que las viejas líneas políticas parecían colapsar. Los liberales enviaron un gran contingente a la Asamblea ( 25 delegados), las dos facciones en que se dividieron los conservadores obtuvieron 20 representantes, mientras que muchos de los escaños restantes (19) fueron para el M-ı 9, un movimiento guerrillero que depuso las armas después de una oferta de paz del presidente Gaviria ${ }^{92}$. Esto llevó a pensar que el viejo sistema de partidos se había fracturado y que sería sustituido por un conjunto de partidos más fuerte e ideológicamente más coherente.

Segundo, a un nivel general, la Asamblea estaba dividida entre dos impulsos que desde entonces han probado estar en fuerte tensión:

${ }^{89}$ Segura y Bejarano $(2004,220)$ dicen que antes de 1991 se consideraba que el sistema político era "muy hostil a la incorporación de nuevos partidos que representaran nuevas demandas e intereses, aparte de los partidos tradicionales".

${ }_{90}$ Cepeda $(1993,265-266)$ y Vila $(2002,269)$. También se consideraba que otra institución que cumplía un papel regresivo y de simple bloqueo era la vieja Corte Suprema (Cepeda, 1993, 257).

91 "Durante mucho tiempo la violencia se interpretó como el resultado de un largo proceso de decadencia del sistema político" (Segura y Bejarano, 2004, 219).

${ }^{92}$ Ver Archer y Shugart (1997, 148-152 y tabla 3.3). 
construir nuevos mecanismos e instituciones que en algún sentido dieran fin a las anteriores o reformar las viejas instituciones para que funcionaran mejor. E1 primer impulso se reflejó en la redacción de una extensa lista de derechos, incluidos muchos DESC (en su mayoría tomados de la Constitución española) y la creación de nuevas instituciones para hacerlos cumplir, basada en la sospecha de que las estructuras existentes no harían cumplir adecuadamente la Constitución y no transformarían la sociedad" ${ }^{93}$. La Asamblea creó un nuevo "Defensor del Pueblo" -encargado de proteger los derechos constitucionales, investigar las violaciones, movilizar a la opinión pública y entablar acciones judiciales- y fortaleció la Procuraduría, a la que dio amplias facultades para investigar y detectar violaciones constitucionales por funcionarios del Estado ${ }^{94}$. Como veremos, la Corte Constitucional a veces recluta a estos actores como aliados.

Aún más importante, la Asamblea Constituyente creó la Corte Constitucional y le dio facultades excepcionales; de hecho, la Corte colombiana debe ser, sea cual sea el indicador, una de las cortes más fuertes del mundo. Tiene la facultad para atender peticiones de revisión abstracta que presente cualquier ciudadano en cualquier momento ${ }^{95}$, y no, como en México, las que presenten unos pocos actores políticos al concluir el proceso legislativo ${ }^{96}$. Además, tiene la facultad para revisar los fallos de tribunales inferiores mediante un procedimiento de reclamación individual de protección de los derechos fundamentales llamado tutela. Las tutelas no son costosas, se atienden rápidamente y se pueden usar para hacer cumplir cualquier derecho "fundamental" consagrado en la Constitución contra cualquier actor público $\mathrm{y}$, en muchas situaciones, también contra actores privados ${ }^{97}$. La Asamblea creó la Corte Constitucional para asegurar que la Constitución se cumpliera aunque los actores políticos tradicionales no fueran reformados.

Vale la pena señalar, además, que es relativamente difícil "empaquetar" a la Corte de nueve miembros, porque en el proceso de selec-

93 Cepeda (1993, 157-170).

94 En ibíd. (101-102) se analizan la creación y los propósitos de estas dos instituciones. E1 Defensor del Pueblo es una institución muy común en los países latinoamericanos, pero sus facultades y su importancia varían ampliamente. Elmendorf (2007, 961-964) examina las diferencias entre defensores del pueblo en algunos países occidentales y no occidentales.

95 Cepeda (2004, 555-556).

96 Navia y Ríos (2005, 208-209) describen la versión mexicana de la revisión abstracta y anotan que las demandas contra leyes federales sólo pueden ser presentadas por un tercio de los diputados o senadores, el fiscal general y los partidos políticos.

${ }_{97}$ Ibíd. (552-554). 
ción participan cuerpos diferentes. Los magistrados son nombrados por períodos no renovables de ocho años, de ternas que tres cuerpos diferentes -el presidente, el Consejo de Estado (la alta corte administrativa) y la Corte Suprema- envían al Senado para que escoja un nombre de cada terna como miembro de la Corte Constitucional ${ }^{98}$. El papel relativamente limitado del presidente ayuda a proteger la independencia de la Corte.

La segunda motivación, reformar las instituciones políticas para que funcionaran mejor, también se reflejó en diversos puntos del trabajo de la Asamblea. Se puede ver en sus esfuerzos para establecer reglas más claras para la declaración de emergencia y el uso de las facultades del presidente, y para dar al Congreso un mayor papel en la supervisión y vigilancia del uso de esas facultades, así como en el nombramiento de algunos funcionarios ${ }^{99}$. Pero la Asamblea no se ocupó de las causas básicas de la disfunción del Congreso. Hizo esfuerzos superficiales para "limpiar" el legislativo ${ }^{100}$, pero los cambios de las reglas electorales empeoraron los problemas de comportamiento del Congreso, y no lo mejoraron ${ }^{101}$. Las nuevas reglas mantuvieron la estructura de lista abierta que daba a los partidos poco control sobre sus candidatos y permitían listas múltiples del mismo partido ${ }^{102}$;

98 Constitución colombiana, art. 239.

99 Ibíd. (arts. 212-215) y Cepeda (1993, 296). E1 propósito no era abolir las facultades de emergencia sino evitar abusos y aclarar cuándo se podían usar. Archer y Shugart $(1997,128,130)$ indican que en la Constitución de 1991 las facultades de estado de sitio siguieron siendo sustanciales y las facultades para emitir decretos económicos se ampliaron en ciertos aspectos.

100 Por ejemplo, declaró ilegal uno de los medios que usaba el presidente para "comprar" a los legisladores: los auxilios parlamentarios o fondos discrecionales que les concedía para cualquier proyecto que desearan (Constitución colombiana, art. 136, num. 4). A pesar de la prohibición, siguen existiendo fondos de esta clase con nombres diferentes (Pizarro, 2006, 96, n. 25).

${ }^{101} \mathrm{E} 1$ cambio más importante de las reglas electorales fue exigir que todos los senadores fueran elegidos por representación proporcional en una circunscripción nacional, lo que facilitó la elección de nuevas fuerzas políticas pero no fortaleció el sistema de partidos (Constitución Colombiana, art. 171). Los "partidos nuevos" que llegaron a la Asamblea estaban obsesionados por la representatividad y no por la coherencia ni la fortaleza del sistema de partidos. De hecho, el aumento del tamaño de las circunscripciones manteniendo la estructura de lista abierta aumenta las presiones sobre los senadores para que busquen reputación individual y no de partido (Carey y Shugart, 1995, 430-432).

102 Pizarro (2006, 84 y n. 17) observa que una ley de 1994 dio técnicamente a las listas de partido el control sobre el rótulo de partido pero que "los partidos tradicionales, igual que muchos partidos nuevos, dan respaldo indiscriminado". Crisp $(2006,218)$ comenta las fallas de los reformadores para eliminar las listas inter-partidos. Una reforma que entró en vigencia en 2006 ordenó una lista por partido y circunscripción (ibíd., 223, n. 4), pero su impacto aún no es claro, pues las facciones pueden actuar como partidos independientes. Quizá induzca la proliferación de partidos pequeños. Un estudio encontró que la reforma redujo notablemente el número de listas en las elecciones de 2006 (Shugart et al., 2007, 251-257). 
además, facilitaron que movimientos transitorios, y no los partidos establecidos, ganaran representación ${ }^{103}$.

\section{LAS INSTITUCIONES POLÍTICAS DESDE 1991 - DETERIORO CONTINUO DEL SISTEMA DE PARTIDOS}

No es entonces sorprendente que los partidos se hayan desinstitucionalizado aun más desde 1991 (aunque sean mucho más abiertos a nuevos intereses) ${ }^{104}$, y que el comportamiento del legislativo haya empeorado notoriamente en años posteriores. Antes de la Asamblea Constituyente de 1991, los dos partidos tradicionales, aunque muy fraccionados, a veces funcionaban como entidades coherentes y daban estructura a la política colombiana. El período de desinstitucionalización de los partidos llegó a su apogeo en 2002, cuando un político de fuera del sistema de partidos, Alvaro Uribe, fue elegido presidente ${ }^{105}$. Los dos partidos tradicionales han estado en declive continuo, hoy ninguno es una entidad poderosa, y los conservadores están esencialmente muertos. Dos tipos de fuerzas políticas nuevas han llenado este vacío, pero ninguna de ellas augura un buen desempeño legislativo.

En primer lugar, hay brotes y facciones de los partidos rurales tradicionales, basados en el cacicazgo, con nuevas etiquetas. Estos partidos son personalistas y están liderados por el mismo tipo de políticos que dirigían las facciones de los partidos Liberal y Conservador ${ }^{106}$; pero están menos atados que antes a un rótulo coherente de partido. Igual que antes de 1991, sus legisladores tienen poco interés en hacer política a nivel nacional ${ }^{107}$. En conjunto, tienden a ser muy pequeños (porque están ligados a actores individuales que en general sólo tienen apoyo en una región del país), y tienden a aparecer y desaparecer con frecuencia, mostrando poca longevidad ${ }^{108}$. La evidencia empírica indica que la disciplina de partido sigue siendo baja, de modo que estos partidos son incapaces de votar como un bloque coherente ${ }^{109}$.

El segundo tipo de legisladores pertenece a lo que varios autores llaman "microempresa electoral"110. Estos son grupos muy pequeños

103 Constitución colombiana, art. 108.

104 "El alcance de la representación política y social se amplió [desde 1991...] muchos partidos ganaron representación en el Senado" (Pizarro, 2006, 88 y tabla 3.3).

105 Cepeda U. $(2008,209)$ señala que "Uribe se presentó como "independiente". 106 Pizarro (2006, 90-91).

107 “Los congresistas colombianos prefiere usar su poder como instrumento para obtener cargos burocráticos y otras ventajas y privilegios. La política pública no es en realidad su principal preocupación” (Cepeda U., 2008, 204).

108 Ibíd. (212).

109 “Los liberales y los conservadores mostraron una propensión a romper la disciplina anterior similar a la de antes de la reforma" (Crisp, 2006, 218).

110 Pizarro (2006, 78). 
de figuras políticas, a menudo celebridades en su carrera anterior, que reciben la mayoría de sus votos de electores urbanos independientes, y que tienden a servir de nicho de intereses políticos: maestros, comunidades indígenas o grupos religiosos protestantes ${ }^{111}$. En la superficie, estos actores prometen tomar decisiones políticas amplias. Pizarro señala que suelen tener inclinaciones programáticas y actúan entonces como líderes en la formulación de políticas en el Congreso ${ }^{112}$. Pero personajes aislados interesados en cuestiones políticas amplias no pueden crear por sí mismos un legislativo que funcione, al menos en la mayoría de los temas. Sin partidos que los reúnan y formen coaliciones, estos legisladores microempresarios tienen grandes dificultades para coordinarse a nivel institucional ${ }^{113}$. Además, la falta de un rótulo real de partido en estas microempresas debilita el vínculo entre los representantes y sus electores; es difícil que los votantes sepan lo que obtendrán cuando depositan el voto.

Los problemas de corrupción han agravado la debilidad del legislativo. El legislativo colombiano está plagado de legisladores que tienen lazos con organizaciones ilegales, en particular con grupos paramilitares. Esto ha provocado una serie continua de investigaciones y expulsiones que lleva a una rotación muy alta y contribuye a paralizar la actividad legislativa. Por ejemplo, de 270 legisladores elegidos para el período 2006-2010 en la Cámara y el Senado, 57 (cerca de la quinta parte) habían sido separados del cargo o eran investigados a comienzos de 2009, tan sólo por vínculos con paramilitares ${ }^{114}$.

Varios estudios indican, entonces, que el comportamiento del legislativo como cuerpo es aún peor que antes de 1991. La mayoría de las propuestas que presentan por legisladores son medidas simbólicas o clientelistas dirigidas a un electorado geográfico particular; casi todas las propuestas nacionales importantes de política siguen siendo presentadas por el ejecutivo ${ }^{115}$. Además, la moneda de negociación en el Congreso sigue siendo la de las partidas y otros recursos particularistas focalizados geográficamente que el presidente ofrece a los legisladores a cambio de votos (en vez de los compromisos políticos) ${ }^{116}$.

111 Ibíd., 90.

112 "Si el Congreso colombiano a veces produce leyes valiosas, esto se debe al liderazgo de la presidencia y de los congresistas más programáticamente orientados” (ibíd.).

${ }^{113}$ Ibíd., 91-92.

${ }^{114}$ López y Sevillano (2008).

115 Pizarro $(2006,91-92)$ cita un estudio que mostró que el $78 \%$ de los proyectos propuestos por legisladores entre julio de 1998 y julio de 1999 tenía un enfoque estrictamente local o regional, mientras que sólo el $22 \%$ abordaba asuntos nacionales. Ver Moreno (2005), que en un estudio de los patrones de presentación de proyectos encuentra que los partidos nuevos se comportaban igual que los viejos.

116 Pizarro $(2006,92)$. 
Así, debido en parte a reformas incompletas y en parte a elementos duraderos de la cultura política, el Congreso ha mantenido su papel tradicional de bloquear la política presidencial ${ }^{117}$, en vez de presentar o reformar iniciativas de política nacional, y de cuerpo que abdica el poder nacional a favor del ejecutivo a cambio de esos pagos.

\section{LAS RESPUESTAS DE LA CORTE COLOMBIANA AL CONTEXTO INSTITUCIONAL}

La Corte Constitucional colombiana se ha convertido en una de las cortes más poderosas del mundo. El alcance y el activismo de su jurisprudencia sobre derechos son impresionantes ${ }^{118}$. La Corte ha dado amplio uso a la extensa y detallada Constitución del país y ha desarrollado una jurisprudencia rigurosa y creativa. Por ejemplo, legalizó el consumo personal de drogas y la eutanasia, con base en el derecho a la autonomía personal y a la dignidad humana ${ }^{119}$. También ha desarrollado un sólido conjunto de DESC, como lo evidencia su decisión de obligar a las entidades públicas a pagar beneficios de jubilación, exigir que las escuelas no expulsen estudiantes que no pueden pagar la pensión y obligar a las entidades de salud pública a pagar el tratamiento de víctimas del sida ${ }^{120}$.

Pero aquí no me propongo describir el corpus del trabajo de la Corte sino examinar su jurisprudencia como respuesta al contexto institucional. Como ya argumenté, en las relaciones entre el poder ejecutivo y el órgano legislativo colombianos existen tres problemas entrelazados: el desbordamiento del ejecutivo, la abdicación del legislativo y su disfuncionalidad. Para la Corte no ha sido fácil discernir cómo responder a esta maraña de problemas, y de hecho dos de sus tres respuestas han sido contraproducentes. Sobre todo en sus primeros años, intentó remediar la disfuncionalidad del legislativo ejerciendo un estricto control del procedimiento legislativo. Al mismo tiempo, impuso límites estrictos a la política autónoma del ejecutivo, ignorando la disfuncionalidad del legislativo y actuando como si éste fuera un socio apropiado del ejecutivo en el diseño de políticas. Ninguno de esos enfoques funcionó bien. Los intentos de reformar el comportamiento del legislativo mediante fallos judiciales fracasaron

117 Pizarro (ibíd., 91) señala que la fragmentación y la indisciplina legislativa se combinan y obligan a una "negociación constante entre el gobierno y congresistas individuales”, que “eleva drásticamente el 'costo de transacción' de llevar adelante la legislación”.

118 Para una revisión enciclopédica de los casos claves de la Corte, ver Cepeda (2004).

119 Ibíd., 578-581.

120 Ibíd., 616-631.

Revista de Economía Institucional, vol. I3, n. ${ }^{\circ} 24$, Primer semestre/2oit, Pp. I3-83 
porque el problema está profundamente arraigado en el sistema de partidos y, así, está más allá del control judicial. Impedir el diseño de políticas autónomo del ejecutivo y obligar a que todas las políticas pasen por el legislativo sería efectivo si el legislativo funcionara bien. Pero donde éste es un punto de veto de baja calidad, que bloquea numerosos proyectos sin reprobarlos por razones políticas, los efectos de conferir poder al cuerpo legislativo son más dudosos. Y su decisión de erradicar la política autónoma del ejecutivo, que históricamente ha sido tan importante en Colombia, ha bloqueado muchas iniciativas de política relevantes sin producir ganancias claras.

Argumento que la respuesta más efectiva de la Corte, la cual predomina en su labor más reciente, es la sustitución del legislativo. Aquí, al menos algunas veces y en algunos asuntos, la Corte interviene y desempeña funciones legislativas esenciales. En otras palabras, se rehúsa a aceptar una línea clara entre funciones judiciales y legislativas. Aunque este tipo de rol sería impropio en un país donde el legislativo funciona bien, argumento que es apropiado en Colombia. La sustitución del legislativo implica una vigilancia sustantiva de las decisiones políticas del ejecutivo, en vez de confiar en que el órgano legislativo las vigile. De modo similar, implica inyectar nuevas políticas en el sistema en una amplia gama de temas, y supervisar esas políticas para asegurar que se lleven a cabo.

La Corte da más legitimidad al desempeño de este rol de sustitución asumiendo algunas atribuciones cuasi legislativas. Como ya comenté, las teorías del rol legislativo en general destacan dos ventajas del legislativo: su legitimidad democrática y su capacidad institucional, en particular para recoger información. La sorprendente popularidad de la Corte colombiana frente a otras instituciones políticas indica que tiene más legitimidad democrática que la mayoría de los cuerpos judiciales. La gente considera que la Corte, y no el órgano legislativo, es la mejor encarnación del proyecto transformador de la Constitución de $1991^{121}$. La Corte necesita esta popularidad para que se acaten sus decisiones y aun para sobrevivir, porque gran parte de la élite política, en particular la de derecha, le ha sido hostil desde sus inicios: desde 1991, la mayoría de los presidentes ha intentado recortar el poder judicial de algún modo, y esos esfuerzos parecen haber fracasado debido principalmente a la red de aliados de la sociedad civil y a la popularidad de la Corte ${ }^{122}$. El vínculo principal entre la Corte y la democracia proviene del hecho de que la Corte debe mantener un alto respaldo público para preservar su poder.

121 Ver la nota 30 y el texto al que acompaña.

122 Para un resumen de estos esfuerzos, ver Cepeda (2004, 691, tabla 6). 
La Corte también ha tomado medidas encaminadas a fortalecer su capacidad para recibir y evaluar información. Como veremos más adelante, su reglamento permite que cualquier ciudadano instaure una demanda de manera informal, y esto ha ayudado a que conozca una amplia gama de problemas sociales importantes. La Corte también realiza sesiones administrativas de estilo legislativo para escuchar los puntos de vista de expertos y grupos de la sociedad civil sobre problemas difíciles. Y, por último, recurre continuamente a un conjunto de instituciones aliadas creadas por la Constitución de 1991, en particular al Defensor del Pueblo, así como a grupos de la sociedad civil, para reunir y evaluar información sobre importantes áreas de política.

En la siguiente sección sintetizo el discurso de la Corte hacia las otras ramas del gobierno y en particular hacia el legislativo. Mi punto es que la Corte entiende en forma bastante realista el contexto institucional. La sección B revisa brevemente sus respuestas fallidas al problema: tratar de arreglar el cuerpo legislativo y refrenar el diseño de políticas autónomo del ejecutivo. La sección C examina la estrategia de sustitución del legislativo y explica por qué es razonable en el contexto colombiano.

\section{A. EL DISCURSO DE LA CORTE SOBRE EL CUERPO LEGISLATIVO:}

\section{LA CORTE ENTIENDE EL CONTEXTO INSTITUCIONAL}

Antes de discutir las decisiones doctrinales de la Corte Constitucional colombiana, debo señalar que ésta tiene una visión realista del contexto institucional y entiende el papel históricamente disfuncional del cuerpo legislativo. Así se manifestó en las entrevistas que hice a cinco magistrados y cinco ex magistrados de la Corte en el año 2009. Ellos señalaron las fallas de otras instituciones políticas, y en particular del Congreso, como una de las razones del significativo papel de la Corte en el sistema político. Por ejemplo, el magistrado Humberto Sierra manifestó que debido a que el legislativo funciona de manera tan deficiente y tiene tan poca legitimidad, "El pueblo protesta ante la Corte y no ante el Congreso; la Corte es más relevante para su vida" ${ }^{123}$. El ex magistrado Manuel José Cepeda argumentó que la Corte basaba su labor en el supuesto de que el "legislativo es irracional, un cuerpo legislativo tan malo que nos hemos visto forzados a una forma muy estricta de control político" ${ }^{124}$.

123 Entrevista con Humberto Sierra, magistrado de la Corte Constitucional colombiana, Bogotá, agosto de 2009.

${ }^{124}$ Entrevista con Manuel José Cepeda, ex magistrado de la Corte Constitucional colombiana, Bogotá, agosto de 2009. 
Estos supuestos también son muy claros en la jurisprudencia de la Corte, que se queja a menudo de que el legislativo no actúa como un cuerpo deliberativo. Tomemos, por ejemplo, un importante caso de 2003 donde en la revisión abstracta la Corte invalidó las reformas del impuesto al valor agregado que habrían ampliado la base para incluir algunos artículos de consumo diario (como la leche) que antes estaban exentos ${ }^{125}$. La Corte criticó duramente al Congreso por aceptar una propuesta de último momento del ejecutivo sin debatirla en forma sustantiva, y concluyó que la reforma "fue el resultado de una decisión indiscriminada de gravar una gran cantidad de bienes y servicios completamente diversos que no estuvo acompañada de la deliberación pública mínima, mediante la cual se materializa el principio de no tributación sin representación” ${ }^{126}$. Así mismo, en la invalidación de un proyecto de reforma del sistema de pensiones que habría hecho más difícil que ciertos empleados recibiesen pensión, reprendió al legislativo por la "ausencia de debate" sobre las disposiciones relevantes. $\mathrm{Al}$ omitir su discusión, el legislativo negó los principios constitucionales que buscan asegurar que la "representación popular tenga una verdadera efectividad [...] y se garanticen [...] el principio democrático y los principios de transparencia y publicidad que deben informar la actividad legislativa"127.

En segundo lugar, el discurso de la Corte muestra que es consciente de que la negociación legislativa es sobre reparto de partidas y no sobre política. En una decisión sobre la constitucionalidad de lo que eran en esencia pagos del ejecutivo de fondos que los legisladores individuales podían usar para lo que desearan, señaló que entendía las "razones" y "la racionalidad empírica" del siguiente argumento que presentó un interviniente, aunque no compartía sus consecuencias normativas:

Debido a la debilidad de los partidos políticos colombianos, la abierta concesión por el gobierno de ciertas partidas a los congresistas, para obtener su apoyo [...] debe ser aceptada [...] Y todo eso [lo] deriva del hecho de que en Colombia los partidos y movimientos políticos no operan como organizaciones coherentes sino como asociaciones de políticos regionales, con prioridades puramente locales y muy específicas ${ }^{128}$.

La Corte tiene aguda conciencia de la dinámica básica de las relaciones entre el legislativo y el ejecutivo en Colombia.

A partir de este contexto institucional la Corte y sus defensores han elaborado una nueva teoría de la división de poderes que se centra en el papel de la Corte como contrapeso del poder ejecutivo

125 Corte Constitucional, Sentencia C-776/03.

126 Ibíd., § VIII.4.5.6.1.

127 Corte Constitucional, Sentencia C-754/04 § 3.3.2.2.2.

${ }^{128}$ Corte Constitucional, Sentencia C-1168/01 § VII, 13. 
e incluso como proponente directo de políticas basadas en valores sustantivos derivados del texto constitucional. En un caso famoso de $1992^{129}$, donde anunció que haría cumplir los DESC usando la tutela en ciertas condiciones, manifestó:

Las dificultades derivadas del crecimiento desbordante del poder ejecutivo en el Estado intervencionista y de la pérdida de liderazgo político del órgano legislativo, deben ser compensadas, en la democracia constitucional, con el fortalecimiento del poder judicial, dotado por excelencia de la capacidad de control y de defensa del orden institucional. Sólo de esta manera puede lograrse un verdadero equilibrio y colaboración entre los poderes; de lo contrario, predominará el poder ejecutivo ${ }^{130}$.

En otras palabras, en un orden institucional donde el cuerpo legislativo es estructuralmente incapaz de hacer contrapeso al ejecutivo, la esperanza es que lo haga una judicatura fuerte. Además, en ausencia de "acción del legislativo", la Corte determinó que debía "dar fuerza" a los principios constitucionales, desarrollando y haciendo cumplir directamente incluso los DESC: "Es claro que en todos estos casos el juez decide algo que en principio le corresponde al legislador. Sin embargo [...] la falta de solución proveniente del órgano que tiene la facultad de decidir, implica la posibilidad de que otro órgano, en este caso el judicial, decida" 131 .

Así, la Corte sostiene que aunque la división de poderes es un principio importante en el derecho constitucional colombiano, es una doctrina flexible, y tiende a subrayar el deber de las ramas de colaborar armoniosamente para lograr los objetivos constitucionales y no la división rígida ${ }^{132}$. En la conciencia de la Corte como "guardiana de la supremacía de la Constitución" ${ }^{133}$ ocupa un primer plano la pregunta de si la sociedad y el Estado se acercan a la visión constitucional establecida en 1991; la división de poderes es un mero instrumento para

${ }_{129}$ Corte Constitucional, Sentencia T-406/92.

${ }^{130}$ Ibíd., § I.C.9.

${ }^{131}$ Ibíd., III.B.19. Los principales defensores de la Corte han hecho eco a este análisis. Por ejemplo, el brillante jurista Manuel José Cepeda, quien se convertiría en su presidente, señaló que las dos principales fuentes de poder de la Corte eran: 1) "la posición central que el Presidente ejercía tradicionalmente [...] sobre el Congreso, que redujo -y en muchos casos distorsionó- el sistema de frenos y contrapesos entre las ramas políticas", y 2) "la percepción de que [la política] es clientelista y beneficia a los políticos y no a la gente común y corriente [...] Los ciudadanos raras vez piensan que las leyes representan el consenso de la sociedad o de una mayoría política sólida” (Cepeda, 2007, 241-242).

${ }_{132}$ Por ejemplo, la concepción de la Corte de la doctrina del "estado de cosas inconstitucional", (ver secc. III.C.2), que fundamenta su capacidad para emitir órdenes estructurales en situaciones que considera abiertamente inconstitucionales, se basa en la idea de "colaboración de manera armónica" y en su rol de "guardiana de la supremacía de la Constitución” (ver Corte Constitucional, Sentencia T-068/98 § IV.10-11; Sentencia T-025/04 § 6.3.2.

${ }^{133}$ Ver Corte Constitucional, Sentencia T-068/98 § IV.11. 
materializar esa visión. Como veremos más adelante, la judicatura está dispuesta a intervenir para restablecer la visión constitucional cuando las demás ramas no actúan o actúan en forma impropia. La afirmación de una concepción particular del rol judicial está subordinada al objetivo de asegurar ese cambio constitucional.

\section{B. INTENTOS FALLIDOS DE “REMEDIAR” LA DISFUNCIONALIDAD DEL LEGIS-} LATIVO Y LIMITAR EL DISEÑO AUTÓNOMO DE POLÍTICAS POR EL EJECUTIVO

Debido a su aguda conciencia del contexto institucional, no es de extrañar que la Corte dedique mucha energía a responder al problema de la debilidad legislativa. Pero no todas sus respuestas han sido eficaces. Sus intentos de mejorar el comportamiento legislativo vigilando el procedimiento legislativo y de limitar el diseño autónomo de políticas por el ejecutivo han bloqueado políticas importantes sin producir beneficios claros. La Corte carece de instrumentos para mejorar el desempeño del legislativo y, en ausencia de un mejor desempeño de éste, ordenar que toda política pase por el Congreso no es una estrategia efectiva.

La Corte ha hecho grandes esfuerzos para mejorar dicho desempeño elaborando extensas doctrinas constitucionales que regulan el procedimiento legislativo. La base de sus doctrinas es la idea de deliberación: el Congreso colombiano "debe ser [...] un espacio de razón pública”, aunque su comportamiento real diverja crudamente de ese fin ${ }^{134}$. En otras palabras, sus decisiones se deberían tomar en público y no en tratos de pasillo o pactos de partidos: "la validez de una decisión mayoritaria no reside solamente en que ésta haya sido adoptada por una mayoría sino además en que ésta haya sido públicamente deliberada y discutida" ${ }^{135}$.

Los principios mencionados dan lugar a dos líneas de doctrina. Con la primera, más estrecha, la Corte busca impedir que el ejecutivo

134 "E1 Congreso es un espacio de razón pública. O al menos, la Constitución postula que así debe ser" (Corte Constitucional, Sentencia C-816/04 § VII.138).

135 Ibíd., § VII.137; ver también ibíd. § VII.138, donde distingue entre "negociaciones entre las fuerzas políticas por fuera de la sesiones parlamentarias", que son "inevitables" pero en tensión con los requisitos constitucionales, y el "modelo deliberativo y público" que desean "las democracias constitucionales" modernas; en ibíd. § VII.127 se cita la Sentencia C-222/97: "Esta Corte había señalado con claridad que en el trámite de los actos legislativos está excluida 'la votación fundada exclusivamente sobre la base de acuerdos políticos externos a la sesión misma, celebrados por grupos, partidos o coaliciones, con la pretensión de imponer una mayoría sin previo debate"'. Las entrevistas con los magistrados confirmaron que estas doctrinas fueron resultado de la irracionalidad que se percibía en el legislativo. El ex magistrado Manuel José Cepeda, por ejemplo, me dijo: "percibíamos que teníamos un Congreso tan malo que no teníamos otra elección que intentar y hacer algo" (entrevista con Manuel José Cepeda, Bogotá, agosto de 2009). 
manipule el proceso legislativo. Por ejemplo, en un caso resonante de 2003, bloqueó los esfuerzos del presidente Uribe para que se adoptara una reforma constitucional que habría establecido medidas radicales contra el terrorismo y la insurgencia ${ }^{136}$. En la votación inicial, la reforma no tuvo votos suficientes para su aprobación; el presidente de la Cámara, aliado de Uribe, cerró la votación con pretextos antes de que finalizara ${ }^{137}$. Al día siguiente, sin ningún debate adicional, 14 legisladores cambiaron su voto. La Corte falló que el intento del presidente de anular la primera votación era inválido, y que se debía mantener esa primera votación, que reprobaba el proyecto. Pero su preocupación básica en este caso era que Uribe hubiera comprado votos adicionales. La Corte comentó en particular que 14 legisladores habían cambiado su voto entre las dos sesiones y juzgó que sus acciones eran "cuestionables" y habían "distorsionado la formación de la voluntad popular" porque el cambio de voto ocurrió "sin que mediara ningún nuevo debate público del asunto en la Plenaria" 138 .

La segunda línea de doctrina está dirigida a la falta de deliberación legislativa incluso en ausencia de interferencia del ejecutivo. Por ejemplo, la Corte declarará inexequibles los actos legislativos cuando los directivos de la cámara no den tiempo para el debate (p. ej., cuando el presidente abra formalmente el debate pero lo cierre inmediatamente y proceda a la votación antes de que hayan hecho pronunciamientos) ${ }^{139}$. También declarará inexequibles los proyectos cuando los directivos de la cámara no hayan leído el registro, o no se haya publicado en la gaceta legislativa o en otra forma el contenido de los proyectos que se sometan a votación, con base en que esto impide el debate y una votación informada ${ }^{140}$. Por último, declarará inexequibles las reformas a un proyecto presentado en la plenaria si es claro que una comisión

136 Corte Constitucional, Sentencia C-816/04.

${ }^{137} \mathrm{E} 1$ presidente manifestó que la sesión se desordenó porque los legisladores de la oposición protestaron por su decisión de levantar la sesión (ibíd. § VII.32).

${ }^{138}$ Ibíd., § VII.127.

139 Ver Corte Constitucional, Sentencia C-754/04 § VI.3.3.2.2.2, que declara inexequibles partes claves de una reforma de las pensiones donde el debate apenas se abrió formalmente y se cerró; la Sentencia C-668/04 § VII.7 deroga por las mismas razones una reforma de la Constitución que habría reorganizado a los gobiernos locales.

${ }_{140}$ Ver Corte Constitucional, Sentencia C-760/01, que declara inexequibles numerosas reformas al nuevo código penal porque no fueron leídas o publicadas antes de la votación. Un magistrado señaló: "Quienquiera que esté familiarizado con el proceso parlamentario reconocerá que los representantes parlamentarios votan a menudo una propuesta sin conocer su contenido, ni siquiera las partes esenciales" (ibíd., Aclaración de voto, 2; Jaime Araújo disiente en parte y concurre en el fallo). 
elude el debate de las disposiciones en cuestión e intenta diferir el debate para una etapa posterior del proceso legislativo ${ }^{141}$.

Aunque estas doctrinas han bloqueado un gran número de importantes medidas de política ${ }^{142}$, poco han logrado a cambio. La Corte afronta la dificultad de usar un instrumento romo - el procedimiento legislativo- para arreglar un profundo problema estructural enraizado en el sistema de partidos y la cultura política del país. Como señaló un estudioso del derecho colombiano, el problema principal del debate legislativo no es que no exista sino que es "desorganizado e ineficaz" porque la debilidad de los partidos lleva a que en el Congreso no se formen bandos ideológicos coherentes ${ }^{143}$. En este contexto institucional, la Corte simplemente no puede fortalecer a los partidos por decisión judicial ${ }^{144}$. La doctrina dirigida a la interferencia del ejecutivo es igualmente ineficaz debido a problemas de detección. Y en la medida en que esta jurisprudencia tenga efecto, el impacto sobre el sistema político será negativo. Como ya expliqué, la manipulación del proceso legislativo mediante la compra de legisladores individuales por el ejecutivo es un mecanismo para afrontar la incoherencia del proceso legislativo; impedirla simplemente frenaría la política legislativa sin mejorar el desempeño ${ }^{145}$.

${ }^{141}$ Ver Corte Constitucional, Sentencia C-801/03 VI.5.1. Ha sido difícil aplicar la doctrina de la Corte porque no hay una manera clara de determinar cuándo un comité intenta eludir su responsabilidad. Ver Corte Constitucional, Sentencia C-370/04, salvamento de voto, Manuel José Cepeda, § 1, que explica la evolución de la doctrina. El magistrado Cepeda, uno de los fundadores de esta doctrina, señaló que se ha vuelto demasiado estricta y ahora tiene el efecto de "castigar la creatividad parlamentaria y petrificar los proyectos de ley a lo decidido en el primer debate".

${ }^{142}$ Ver Corte Constitucional, Sentencia C-754/04, que declara inexequibles partes claves de una ley que buscaba reducir los pagos de pensiones; Sentencia C-668/04, acerca de las normas constitucionales sobre la composición de las asambleas departamentales; Sentencia C-372/04, sobre una reforma de la Constitución que modifica las atribuciones del Congreso; Sentencia C-370/04, sobre exención del IVA a productos agrícolas; Sentencia C-1147/03, sobre el IVA a juegos de suerte y azar; Sentencia C-801/03, sobre partes de un proyecto para flexibilizar las leyes laborales; Sentencia C-760/01, sobre reformas al código penal.

${ }_{143}$ Falla (2001, 216); "necesitamos construir un sistema de partidos para que los principios democráticos sean efectivos en la participación en el Congreso" (ibíd., 221).

${ }^{144}$ No argumento que la doctrina judicial no tenga impacto en el sistema de partidos. Gran parte del edificio de la ley electoral en Estados Unidos se basa en el supuesto de que sí lo tiene. Tampoco digo que el control judicial del procedimiento legislativo sea siempre fútil; puede ser, como sostiene Cass Sunstein, que los jueces puedan y deban ordenar que los legisladores deliberen ciertos asuntos (Sunstein, 2000, 338-339). Mi punto aquí es más simple: el mejoramiento judicial del desempeño legislativo es imposible donde los problemas de desempeño del legislativo tienen origen en profundos problemas del sistema de partidos, como los que se observan en Colombia.

${ }_{145}$ Así, quizá por prudencia, la Corte se ha alejado del control del proceso legislativo en la jurisprudencia más reciente. Por ejemplo, en un caso resonante 
La Corte también ha desarrollado doctrinas que reducen notoriamente la capacidad del presidente para diseñar políticas en forma autónoma (es decir, sin pasar por el proceso legislativo), bien sea por facultades delegadas o por decretos de emergencia ${ }^{146}$. Sostiene que no debe propiciar la delegación de facultades extraordinarias y que debe interpretarlas con "carácter restrictivo" en todos los contextos ${ }^{147}$; su objetivo es "reducir la capacidad del Gobierno para ejercer funciones legislativas por delegación del Congreso" ${ }^{148}$. Así, la Corte ha desarrollado doctrinas poderosas que invalidan delegaciones insuficientemente precisas $^{149}$ (una versión colombiana de la doctrina de no delegación) y limitan su alcance ${ }^{150}$.

más reciente sobre una reforma de la Constitución para permitir que el presidente Uribe y los futuros presidentes pudieran ser reelegidos por otro período, enfrentó artimañas similares a las que se usaron en el caso de la reforma contra el terrorismo. Las directivas de la Cámara no llamaron a los opositores del proyecto para que criticaran la ponencia, abrieron y cerraron los debates inmediatamente, y permitieron que muchos representantes votaran a pesar de tener parientes empleados en la administración Uribe (ver García, 2007, quien entrevista a Catalina Botero M., profesora de derecho constitucional y magistrada auxiliar de la Corte Constitucional). La Corte, no obstante, mantuvo la medida (Corte Constitucional, Sentencia C-1040/05).

${ }^{146}$ Los presidentes colombianos tienen varios tipos de facultades delegadas para emitir decretos: pueden expedir decretos cuyo rango es igual al de los estatutos cuando el órgano legislativo les delega facultades extraordinarias, o bien decretos administrativos cuyo rango es inferior al de los estatutos del Congreso, pero que precisan o regulan esos estatutos (Julio, 2003, 75-88). Aquí discuto el primer tipo; no trato el uso del segundo tipo porque es revisado por un cuerpo diferente, el Consejo de Estado.

${ }_{147}$ Ver Corte Constitucional, Sentencia C-702/99 § VI.4.3: "Al adoptar esta decisión, la Corte Constitucional se inspira además en el carácter restrictivo que debe guiar la interpretación constitucional en materia de facultades extraordinarias al Gobierno".

${ }_{148}$ Corte Constitucional, Sentencia C-702/99 § VI.4.1.

${ }^{149}$ Igual que otras cortes que han intentado hacer cumplir una doctrina de no delegación -ver, p. ej., Currie $(1994,133)$ quien explica que los casos alemanes de no delegación son "numerosos y no todos fáciles de reconciliar"- la Corte colombiana ha tenido problemas para determinar exactamente qué estándares aplicar, aunque el más repetido es que la delegación debe ser "específica, cierta y exacta”. Ver la Sentencia C-097/03, que declaró inexequible una delegación por ser muy vaga, pues simplemente daba instrucción al presidente para "organizar un sistema de inspección, vigilancia y control, adaptable a distintos tipos de instituciones y regiones, para enfrentar situaciones especiales”, sin decir cuál sería el propósito del sistema ni definir "situaciones especiales". La Sentencia C-1493/00 rechazó la redacción que permite al presidente "dictar otras disposiciones" y dictar "otras normas relacionadas con esta materia". La Sentencia C-1374/00 § V declaró inexequible la delegación de facultades para "dictar normas sobre policía judicial en lo que no corresponde a las materias reguladas por los códigos Penal y de Procedimiento Penal”, en razón de que esta delegación era amplísima o sumamente general.

${ }^{150}$ Ver Corte Constitucional, Sentencia C-734/05, que declaró inexequible un decreto que fijaba el monto del salario utilizado para calcular las pensiones porque la delegación legislativa sólo se concedió al presidente para expedir normas 
Con respecto a los decretos de emergencia, las estadísticas brutas demuestran el activismo judicial: de 12 declaraciones presidenciales de estado de emergencia desde 1991, la Corte declaró que 3 eran totalmente inexequibles y 3 más parcialmente inexequibles. Y aunque haya respaldado una declaración de estado de emergencia, ha derogado decretos substantivos expedidos durante la vigencia del estado de emergencia ${ }^{151}$. Además, la mayoría de las aprobaciones de facultades para emitir decretos ocurrieron en sus primeros años de existencia: respaldó totalmente 5 de 6 decretos entre 1992 y 1994, pero desde entonces ha declarado inexequibles, al menos en parte, 5 de 6 declaraciones de emergencia ${ }^{152}$. El país estuvo el $82 \%$ del tiempo bajo algún tipo de estado de emergencia en los años setenta y ochenta del siglo XX, y sólo el 17,5\% del tiempo entre 1991 y $2002^{153}$.

Conocidos analistas locales han elogiado la jurisprudencia de la Corte sobre facultades de emergencia como "una de [sus] intervenciones más importantes y originales" 154 . Pero este tipo de jurisprudencia estructural -que busca que todo el diseño de políticas pase por el legislativo- ignora el problema de la debilidad legislativa. Igual que la manipulación del proceso político por el ejecutivo, su diseño de políticas autónomo ha sido un mecanismo para enfrentar graves problemas de desempeño del legislativo. En la medida en que el cuerpo legislativo siga siendo disfuncional, ordenar que toda política pase por el Congreso añade un punto de veto de baja calidad al proceso del diseño de políticas y es probable que bloquee un gran número de proyectos sin lograr resultados positivos ${ }^{155}$.

relacionadas con las condiciones de circulación de los "bonos pensionales", y no para regular las pensiones. Ver Cepeda (2004, 636, n. 299), donde se mencionan numerosos casos.

${ }^{151}$ Ver Revenga y Girón (2004, 40-49).

152 Uprimny (2004, 57, tabla 1).

${ }^{153}$ Ibíd., 65 y tabla 3.

${ }^{154}$ Ibíd., 47.

${ }^{155} \mathrm{La}$ jurisprudencia de la Corte sobre las facultades de emergencia no carece de méritos. Como sostiene Tushnet, una corte puede controlar estas facultades de dos maneras: revisando independientemente la acción del ejecutivo por preocupaciones acerca de derechos substantivos, o estableciendo controles estructurales a la acción del ejecutivo, diciéndole que debe acudir al Congreso para lograr lo que desea (Tushnet, 1998). Gran parte de la jurisprudencia colombiana es puramente estructural, lo que es inapropiado en vista de la disfunción del legislativo. Pero algunos de los casos, en particular cuando el presidente declaró el "estado de conmoción interna" para enfrentar la insurgencia, tratan realmente de derechos. La Corte les dice a las ramas políticas que lo que desean hacer es inconstitucional, independientemente de la fuente. Ver, por ejemplo, la Sentencia C-300/94, que declara inexequible una declaración de estado de conmoción interna para impedir la liberación inminente de prisioneros debido a largos retrasos en el manejo de los casos, con argumentos de debido proceso. En mi opinión, este tipo de supervisión judicial se ajusta bien al contexto institucional y es parte de 
Históricamente, los gobiernos colombianos han recurrido a decretos de emergencia para enfrentar graves crisis económicas. Como el Congreso funcionaba tan mal, el presidente a menudo aprobaba estos proyectos por sí solo. Los redactores de la Constitución de 1991 entendieron esta necesidad e incluyeron una cláusula de "emergencia social, económica y ecológica”, para enfrentar crisis socioeconómicas (y no de seguridad) ${ }^{156}$. La Corte ha limitado severamente este mecanismo confinándolo a situaciones donde haya habido un fuerte choque exógeno al sistema, como un desastre natural ${ }^{157}$. Por ejemplo, en 1997 declaró inexequible un intento del gobierno de declarar un estado de emergencia económica para enfrentar graves problemas de balanza de pagos ocasionados por un déficit fiscal creciente que amenazaba a la economía ${ }^{158}$. La Corte subrayó que el problema era estructural y de "duración prolongada" 159 , y reiteró que "la utilización expansiva de los poderes excepcionales de la emergencia para resolver problemas crónicos o estructurales" estaba prohibida por la Constitución ${ }^{160}$. Lo que significaba, en general, que los problemas estructurales se deben tratar por la vía constitucionalmente "privilegiada" del debate democrático en el Congreso, "el foro natural para discutir y resolver situaciones críticas de esa naturaleza" ${ }^{161}$.

La Corte reiteró esta doctrina ante una declaración de emergencia de 1999, durante la misma recesión económica, en un momento en que los problemas se extendían al sector financiero. El gobierno, amoldándose a las anteriores posiciones doctrinales de la Corte, intentó atribuir el origen de la crisis a un choque externo: "el reciente agravamiento de la crisis económica internacional", que ha "generado una reducción del flujo neto de capital extranjero"162. La Corte rechazó esta premisa, argumentando que el "agravamiento de la crisis financiera internacional, aunque incidió, no constituyó la causa determinante

la estrategia de sustitución del legislativo que se describe más adelante porque la Corte hace su propia revisión sustantiva de las medidas en vez de trasladarlas al control del Congreso (ver secc. III.C.3).

156 Constitución colombiana, art. 215. La Asamblea también estableció otros dos otros estados de emergencia: el estado de conmoción interior y el estado de guerra externa. El primero, para tratar graves disturbios internos relacionados con asuntos tales como la insurgencia guerrillera, y el segundo, que nunca se ha utilizado, para tratar estados de emergencia durante la guerra con un país extranjero (ibíd., arts. 213-214).

157 Ver Corte Constitucional, Sentencia C-216/99, terremoto; Sentencia C-366/94, terremoto.

${ }^{158}$ Ver Corte Constitucional, Sentencia C-122/97 § III.17-III.34.

159 Ibíd., § III.11.

${ }^{160}$ Ibíd., § III.6.

${ }^{161}$ Ibíd., § III.5.

${ }^{162}$ Corte Constitucional, Sentencia C-122/99 § C.I.2. 
y específica de la reducción de los flujos netos de capital externo”163. Observó que la crisis obedecía ante todo a factores fiscales crónicos como el déficit presupuestal y el comercial, redujo notoriamente el alcance de las facultades extraordinarias del gobierno, y sólo las mantuvo para ciertos sectores de la actividad financiera ${ }^{164}$.

La doctrina de la Corte que privilegia los choques externos sobre los factores crónicos y estructurales puede aparejar algunos problemas debido precisamente a que no es sensible al contexto institucional local. Esta clasificación tiende a limitar esas facultades a una clase definida de acontecimientos que involucran desastres ${ }^{165}$, e ignora las fallas institucionales que han plagado al país durante mucho tiempo. Ignorar estos factores no los hace desaparecer; suponer que el cuerpo legislativo funciona bien no lo hace funcionar bien ${ }^{166}$. Es posible que el trámite de reformas que recortan el presupuesto y los impuestos en un órgano legislativo disfuncional, con partidos débiles, sea lento y pueda resultar imposible. Los estudiosos han encontrado evidencia de un vínculo entre la jurisprudencia posterior a 1991, que da al presidente poca capacidad para actuar unilateralmente en temas económicos, y el empeoramiento del déficit fiscal del país ${ }^{167}$. La crisis económica de finales de los años noventa no acabó rápi-

163 Ibíd.

164 Uno de ellos, el de deudores del sistema UPAC, en cuyo nombre la Corte intervendría una y otra vez en el período 1999-2002 (ver secc. III.C.1).

${ }^{165}$ Ver Corte Constitucional, Sentencia C-216/99, terremoto; Sentencia C-027/96, asesinato de líderes políticos, y Sentencia C-366/94, terremoto.

166 La ironía es que la desconfianza de la Corte en la capacidad del legislativo para supervisar al ejecutivo es una de las razones para hacer más estricta su jurisprudencia estructural. Los redactores de la Constitución querían que el Congreso cumpliera un rol importante en la supervisión de las facultades de emergencia. Por ejemplo, exigieron que ciertas prórrogas de estas facultades más allá del plazo inicial fueran aprobadas por el Senado. Además, permitieron que el Congreso derogara por resolución conjunta algunos estatutos expedidos mediante facultades extraordinarias. Aunque la Corte inicialmente dio gran peso a este control político (ver Corte Constitucional, Sentencia C-004/92 VII.21, donde señala que el control político del Congreso "cumple una función democrática de contrapeso"), han crecido sus sospechas sobre el rol del legislativo en la supervisión del presidente (ver la Sentencia C-327/03 §§ V.4.5, V.4.6, donde niega la prórroga de un estado de conmoción interna aprobado por el Senado porque la sesión fue apresurada e insuficientemente deliberativa, porque el Senado no presentó un documento que explicara por qué era necesaria la prórroga y porque fue aprobada antes de que transcurriera la mitad del período inicial de emergencia. Esta sospecha es justificable y debería llevar a una supervisión sustantiva más estricta de los decretos presidenciales para asegurar que concuerden con los valores constitucionales (ver la nota 155). Pero usar la sospecha de la función de control político del legislativo para restringir el poder del ejecutivo con argumentos puramente estructurales es contraproducente porque da poder a una institución disfuncional.

167 Cárdenas et al. (2008, 228). 
damente sino que llevó a Colombia a una de las peores recesiones de su historia ${ }^{168}$. Además, muchas reformas económicas claves no se podían tramitar en el Congreso hasta que el presidente Uribe llegó al cargo en 2002.

\section{LA CORTE COMO SUSTITUTO PARCIAL DEL LEGISLATIVO}

Los intentos de "arreglar" el órgano legislativo y trasladarle la política no han funcionado bien porque sus problemas de desempeño tienen origen en el sistema de partidos y en su mayor parte están fuera del control de la Corte. A menudo, ésta ha sido más eficaz cuando ha "sustituido" abiertamente al legislativo. Este tipo de sustitución ha operado de varias maneras. Primera, la Corte a veces ha sustituido al legislativo en su rol de presentación de políticas, al introducir directamente nuevas e importantes iniciativas de política en el sistema cuando ha juzgado que las demás ramas han ignorado un tema de importancia constitucional. Segunda, en ocasiones ha asumido el rol del legislativo de hacer cumplir las políticas asegurando la puesta en práctica de sus propias iniciativas de política. Tercera, a menudo ha asumido la función legislativa de vigilar al ejecutivo mediante el desarrollo de una densa jurisprudencia sobre derechos que ha usado para controlar la política del ejecutivo, aunque el legislativo haya aprobado esa política. A continuación examino estas tres áreas.

\section{Presentación de políticas}

La Corte normalmente interviene cuando piensa que otras ramas del gobierno no presentan políticas en áreas claves. Es muy conocido que en el período 1999-2000 decidió una serie de casos que obligaron a revisar el sistema hipotecario. Colombia sufrió una crisis hipotecaria debido al aumento de las tasas de interés y al descenso de los salarios reales (las causas subyacentes fueron las crisis fiscal y financiera que dieron lugar a los decretos presidenciales que discutí más atrás). En algunos años anteriores un gran número de deudores hipotecarios (cerca de 200.000) había incumplido los pagos o estaba en peligro de incumplirlos, y las ramas elegidas no habían dado respuesta ${ }^{169}$. Desde el punto de vista del Estado, el presidente estaba preocupado por la crisis macroeconómica e hipotecaria, las entidades financieras internacionales y el sector financiero, mientras que el Congreso era

168 Echavarría et al. (2005, 34-35).

${ }^{169}$ Uprimny $(2006,136)$ observa que la cuarta parte de los deudores del sistema UPAC, 200.000 de 800.000 , estaba en peligro. 
demasiado disfuncional para actuar. Un componente importante del sistema era una fórmula, la UPAC, que ajustaba anualmente los contratos hipotecarios por la tasa de inflación del año anterior. Con una historia de inflación moderada a alta como la de Colombia, esta fórmula de ajuste era necesaria para un mercado de financiación de largo plazo; sin ella, la incertidumbre sobre la inflación futura podría impedir la realización de la mayoría de los contratos hipotecarios. De acuerdo con las directrices establecidas por un decreto en uso de facultades extraordinarias de 1993, el banco central tenía discreción para determinar estos ajustes.

La Corte actuó de inmediato para reducir las tasas de interés atacando algunos aspectos de la fórmula de la UPAC. En su primera decisión, declaró inconstitucional una disposición que exigía que el banco central fijara los ajustes de la UPAC de acuerdo con las tasas de interés existentes en la economía colombiana ${ }^{170}$. Señaló que había una diferencia entre la tasa de inflación (que mide el poder adquisitivo del dinero) y la tasa de interés (que mide los rendimientos del dinero), y que esta última normalmente era mayor debido a los rendimientos del capital y al riesgo. Por tanto, el indicador de tasa de interés "destruía” el equilibrio entre el deudor y el acreedor e iba en contra de la promoción de la vivienda, un valor protegido constitucionalmente ${ }^{171}$. En otras decisiones sustantivas, la Corte prohibió la capitalización de intereses y las sanciones por pago anticipado de las hipotecas, sosteniendo que eran onerosas para los propietarios ${ }^{172}$.

En otra decisión, de septiembre de 1999, extendió las doctrinas existentes ${ }^{173}$, para encontrar que el presidente había dictado normas sobre la UPAC en forma impropia pues se requería un estatuto para dicha acción. De modo que declaró inconstitucional todo el conjunto de normas existentes, pero aplazó su exclusión del orden jurídico hasta

170 Corte Constitucional, Sentencia C-383/99.

${ }^{171}$ Ibíd., § VII.4.7.

${ }^{172}$ Corte Constitucional, sentencias C-747/99, capitalización, y C-252/98, pago anticipado.

${ }_{173}$ Como señalaron los magistrados disidentes, la Corte podía haber llegado fácilmente a la conclusión opuesta. La mayoría adujo que las normas financieras básicas, incluidas las pautas del sistema UPAC, eran constitucionalmente una ley marco que según la Constitución de 1991 debía ser expedida por el legislativo. De modo que derogó el decreto que reglamentaba las normas expedido por el presidente en uso de facultades extraordinarias (Sentencia C-700/99 VII.3). E1 problema del fallo es que el decreto de 1993 simplemente integraba con otra numeración el material estatutario existente tomado de varias fuentes; nada nuevo añadía al sistema (ibíd., Cifuentes y Naranjo disintieron). La Corte antes había sostenido, con respecto a este mismo estatuto, que el uso de esas facultades no era un intento de crear una ley marco, porque no implica discreción ni poder sustantivo (ibíd.). 
que finalizara la legislatura (del año 2000) ${ }^{174}$. Como señalaron varios disidentes, era evidente que la motivación real de la Corte era forzar cambios legales en toda la estructura, incluso en algunas disposiciones que habría sido difícil invalidar de manera sustantiva ${ }^{175}$. También ordenó que se diera cumplimiento inmediato a su jurisprudencia sustantiva anterior sobre el cálculo de la UPAC y que se devolvieran a los deudores todos los intereses excesivos que hubieran pagado en el pasado; así dio a los deudores alivio inmediato para sortear la crisis ${ }^{176}$.

Un mes después, en octubre de 1999, el presidente presentó una nueva ley al Congreso que fue aprobada a comienzos de 2000. La ley incorporaba la jurisprudencia sustantiva anterior -prohibía la capitalización de intereses y las sanciones por pago anticipado, exigía que el nuevo sistema UPAC sólo reflejara los cambios en la tasa de inflación- y hacía retroactivos todos estos cambios, de modo que reembolsaba a los deudores el pago excesivo ${ }^{177}$. También incorporaba un sinnúmero de disposiciones que la Corte no había exigido expresamente pero que eran de su agrado, como una inyección de dinero del Estado para ayudar a los deudores con estrechez de recursos. Aun así, al final la Corte hizo uso extensivo y creativo de la doctrina de decisión condicional -que le permite aprobar la constitucionalidad de un proyecto a condición de que sea interpretado de cierta manera- para reescribir grandes porciones del estatuto. Y, más importante, impuso topes específicos a las tasas de interés de vivienda, exigiendo que no fueran mayores a "la menor de todas las tasas reales que se estén cobrando en el sistema financiero" "178. También exigió que las reliquidaciones de los deudores morosos fueran iguales a las de los que estaban al día ${ }^{179}$.

Al final, la Corte logró forzar una reforma de largo alcance en el sistema de financiación de vivienda que era más favorable para los deudores futuros y protegía a muchos deudores existentes. Pero la decisión fue criticada por varias razones. En estos casos, igual que en otros, los disidentes argumentaron que la Corte estaba intentando resolver problemas sociales, en vez de actuar como una Corte Constitucional; admitieron que el sistema UPAC se había convertido en un

${ }^{174}$ Corte Constitucional, Sentencia C-700/99 VII.5.

175 Ibíd., § 32 (Cifuentes y Naranjo disintieron): "En ausencia de un verdadero 'vicio constitucional' [...] lo que se percibe es la utilización de la jurisdicción constitucional para propósitos ajenos a su objeto".

176 Corte Constitucional, Sentencia C-700/99 VII.5.

177 Corte Constitucional, Sentencia C-955/00, §§ 3, 17 donde cita la Ley 546 de 1999.

${ }_{178}$ Ibíd., § V.B.4.

179 Ibíd., § V.B.21.

Revista de Economía Institucional, vol. I3, n. ${ }^{\circ} 24$, Primer semestre/2oit, Pp. I3-83 
desastre y que las ramas políticas no estaban resolviendo el problema, pero señalaron que la Corte debilitaría su legitimidad si empezaba a actuar como un cuerpo legislativo:

El respeto por el Estado de derecho y el principio democrático, obliga a la Corte a abstenerse de extender el imperio de su jurisdicción a la resolución de problemas sociales que requieren de instrumentos y de la puesta en obra de políticas por parte de otros órganos del Estado.

La Corte en esta sentencia definió equivocadamente como problema de constitucionalidad, un complejo asunto en el que militan sólo razones de conveniencia y de diseño o rectificación de políticas bajo la responsabilidad de las instituciones encargadas del manejo económico del Estado. La ausencia de liderazgo en un país que no enfrenta sus grandes conflictos ni sus causas, por el momento oculta la improcedencia de la acción de la Corte y lleva a mirar con indulgencia su evidente extralimitación. Pero el costo enorme de este tipo de intervenciones, así ellas puedan por el momento ser muy populares, gravitará negativamente sobre la jurisdicción constitucional que, a la postre, no resiste tamaña desfiguración ${ }^{180}$.

Las innovaciones procedimentales del caso confirmaron que la Corte estaba asumiendo un nuevo papel. En julio de 1999 realizó una sesión pública al estilo de un comité legislativo o una entidad administrativa, en la que escuchó a unos 25 dirigentes y funcionarios, incluidos el Defensor del Pueblo, el ministro de Vivienda, el director del banco central, varios representantes y senadores, los presidentes de algunos gremios de empresarios y el presidente de una asociación de sindicatos de trabajadores ${ }^{181}$. Además, en el proceso pidió y recibió comentarios escritos sobre el problema en cuestión a un número extraordinario de personajes -economistas, académicos, funcionarios públicos-y grupos de la sociedad civil ${ }^{182}$. Finalmente, la Corte obtuvo información sobre la crisis hipotecaria del alto número de tutelas que se habían cursado sobre el tema. Estos mecanismos resolvieron, al menos en parte, el déficit de información que enfrentaba.

También se criticó a la Corte por usar su jurisprudencia de vivienda en beneficio de la clase media y no de los más pobres ${ }^{183}$. Sólo

180 Corte Constitucional, Sentencia C-383/99. Ver el texto que acompaña a las notas 266-267, donde se describe la respuesta de varios comentaristas de la acción de la Corte.

${ }^{181}$ Ver Corte Constitucional, Sentencia C-700/99 § VI, donde describe la sesión pública y los asistentes. "La sesión pública remplaza al Congreso al convocar presumiblemente a todos los intereses involucrados, con el agravante de que no hay una representación proporcional que surja del sufragio universal sino de las posiciones con las que simpatiza la mayoría de la Corte Constitucional" (Kalmanovitz, 2000, 2).

${ }^{182}$ Ver Corte Constitucional, Sentencia C-955/00 § III, donde presenta la lista de invitados que dieron declaraciones; Sentencia C-700/99 $\S \mathrm{V}$, sobre el mismo tema.

183 “La gente más pobre que tiene acceso a la vivienda propia que es expoliada por los urbanizadores piratas [...] que cobran 4 y 5 veces la tasa del sistema 
la clase media, no los pobres, tenía hipotecas, por lo menos en el sector formal. Proteger a la clase media y no a los pobres es una característica general de su jurisprudencia: aunque la Corte protege a grupos muy marginados y ha desarrollado una teoría constitucional de reforzamiento-representación (à la John Hart Ely) para justificar su labor, muchas de sus intervenciones importantes han sido a favor de estratos medios ${ }^{184}$. Pero en un sistema político que funciona de modo tan deficiente, ésta no es necesariamente una recusación de su labor. Cuando protege a estratos medios por incumplimiento de hipotecas y reducciones de salarios, protege a grupos que deberían tener recursos dentro del proceso político ${ }^{185}$.

Un punto final es que la labor de la Corte es aquí diferente del modelo dialógico de cumplimiento de los DESC utilizado en Suráfrica y descrito por Tushnet y otros ${ }^{186}$. En este modelo dialógico, la Corte define el derecho constitucional pero trata intencionalmente de dejar amplio espacio para que los procesos democráticos operen y produzcan un plan de acción específico. La estrategia de la Corte colombiana implicaba alguna cooperación de las otras ramas, en particular del ejecutivo, pero su objetivo principal no era catalizar procesos democráticos sino emprender cualquier acción que juzgara necesaria para resolver problemas políticos. Por tanto, no sentía temor a emitir directivas precisas desde comienzos del proceso ni a revisar extensamente proyectos provenientes del legislativo. De nuevo, este enfoque parece más razonable donde la capacidad del Congreso para comprometerse con los proyectos es limitada por la debilidad de sus partidos.

financiero al enfrentar altos riesgos de no-pago, tampoco se benefició para nada de las sentencias. Los todavía más pobres que viven en los inquilinatos [...] tampoco fueron protegidos" (Kalmanovitz, 2000, 8). Aun los defensores de la labor socioeconómica de la Corte señalaron que las decisiones de vivienda beneficiaron principalmente a la clase media. Uprimny $(2006,136)$ dice que "los deudores eran principalmente de clase media".

${ }^{184}$ Ver Corte Constitucional, Sentencia C-1433/00, donde falló que el Estado no podía congelar los ingresos de los trabajadores del Estado que devengaban más de dos veces el salario mínimo nacional.

185 Kim Scheppele utiliza el ejemplo húngaro y da una razón por la cual los actores políticos domésticos suelen ignorar a los estratos medios en el mundo en desarrollo (Scheppele, 2004, 1941-1949). Los ejecutivos sufren fuertes presiones de organizaciones internacionales que quieren que reduzcan los costos y a menudo son hostiles al gasto social dirigido a la clase media. Otras instituciones domésticas, como los cuerpos legislativos, deberían defender a estos grupos pero los problemas de representación son tan graves que les impiden defenderlos. Así, la Corte actúa como catalizador de un amplio conjunto de intereses domésticos que quedan totalmente excluidos del resto del proceso.

${ }_{186}$ Tushnet $(2008,227-264)$ y Dorf y Sabel $(1998,267)$. 


\section{Supervisión de importantes iniciativas de politica}

La Corte no ha quedado satisfecha con la simple introducción de nuevas ideas políticas en el sistema, también ha dedicado grandes esfuerzos a la supervisión del cumplimiento de esas políticas. La doctrina del estado de cosas inconstitucional es uno de sus principales instrumentos a este respecto. Cuando declara un estado de cosas inconstitucional, declara inconstitucional "la vulneración de los derechos fundamentales de una multitud de personas, cuya solución requiere la intervención de distintas entidades" ${ }^{187}$. La jurisprudencia sobre el estado de cosas inconstitucional tiene semejanzas con la orden judicial estructural estadounidense pero es de mayor escala y más centralizada. Mientras que las órdenes judiciales estructurales suelen ser supervisadas por los tribunales de distrito e involucrar instituciones de una localidad, la misma Corte Constitucional supervisa los estados de cosas inconstitucionales, y a menudo declara que abarcan a todo el país y a un grupo de escala nacional ${ }^{188}$. Además, aunque a veces ha declarado estados de cosas inconstitucionales para remediar problemas de grupos que podrían estar mal representados en un sistema que funciona bien, como los presos y los desplazados por un conflicto civil ${ }^{189}$, también los ha usado para atender a grupos que deberían ser políticamente poderosos, como los pensionados y los abogados que aspiran a ser notarios ${ }^{190}$. La Corte concibe la doctrina del estado de cosas inconstitucional menos como un remedio para grupos particulares y más como un estado de cosas general contrario a lo que ordena la Constitución. La doctrina es entonces congruente con su visión de la Constitución como un documento transformador y con su rol de velar para que la aspiración constitucional y la realidad empiecen a concordar. Es también congruente con una concepción del rol judicial que se basa en la "cooperación armoniosa" entre las ramas, y no en un conjunto de roles predeterminado ${ }^{191}$.

El caso del desplazamiento interno es quizá el más ilustrativo. Se calcula que hay entre 2 y 3 millones de colombianos desplazados de sus hogares debido a la prolongada y compleja insurgencia guerrillera

187 Ver Corte Constitucional, Sentencia T-025/04 § III.7, donde explica los orígenes de la doctrina y su aplicabilidad.

${ }_{188}$ Corte Constitucional, Sentencia T-025/04, tipo de desplazados a escala nacional; Sentencia T-153/98, tipo de presos a escala nacional.

${ }^{189}$ Corte Constitucional, Sentencia T-025/04, refugiados; Sentencia T-153/98, presos.

${ }^{190}$ Corte Constitucional, Sentencia SU-090/00, pensiones; Sentencia T-1650/00, notarios.

${ }^{191}$ Ver el texto que acompaña a las notas 132-133.

Revista de Economía Institucional, vol. i3, n. ${ }^{\circ}$ 24, Primer semestre/2oit, pp. i3-83 
y paramilitar ${ }^{192}$. Típicamente, el Estado ha hecho muy poco por estas personas, a pesar de sus innumerables problemas: tienen dificultades para recibir alimentos o atención médica, sus hijos suelen quedarse sin educación, afrontan graves problemas de seguridad, tienen problemas para restablecer el derecho a la tierra que fueron forzados a abandonar y a menudo son presionados para que regresen a sus hogares antes de que puedan hacerlo con seguridad ${ }^{193}$. El problema es entonces policéntrico, y no el tipo de problemas que la Corte suele abordar. Pero en 2004 ésta declaró un estado de cosas inconstitucional con respecto a toda la población desplazada, sosteniendo, después de revisar las estadísticas, que sus problemas eran masivos y que la respuesta del Estado, en términos de capacidad y presupuesto, era "gravemente deficiente" 194.

Reflejando su enfoque típico del estado de cosas inconstitucional, la Corte hizo la declaración sólo después de recibir una oleada de tutelas relacionadas con un tema particular en un periodo de tiempo sostenido $^{195}$. Así, igual que en los casos de vivienda, usó la acción de tutela, de fácil acceso, como palanca para recibir buena información sobre problemas ampliamente difundidos en la sociedad colombiana. Desde la declaración del estado de cosas inconstitucional, la Corte ha usado diversas técnicas para recibir información razonable relevante para la política. Después ha impartido numerosas órdenes sobre el caso; la mayoría pidiendo información a diversas entidades, en particular sobre cuánto dinero gastan en el problema y cómo lo gastan $^{196}$. También se ha apoyado en un conjunto de ONG nacionales y transnacionales amigables, en grupos de desplazados y en instituciones aliadas creadas por la Constitución de 1991, especialmente el Fiscal General y el Defensor del Pueblo, para supervisar el desempeño de

192 Ver Easterday $(2008,5)$.

${ }^{193}$ Ibíd., 6-7.

${ }^{194}$ Corte Constitucional, Sentencia T-025/04 III.6.2-6.3. El artículo $2^{\circ}$ de la Constitución colombiana dice que "garantizar la efectividad de los principios, derechos y deberes consagrados en la Constitución" es un "fin esencial del Estado". La Corte conceptuó que esto crea el deber del Estado de tomar medidas positivas con respecto al problema de los desplazados, aunque no tenga la responsabilidad principal en la creación del problema (ibíd., § III.8).

195 Ibíd., § III.7, donde señala el "elevado volumen de acciones de tutela presentadas por personas desplazadas para obtener distintas formas de ayuda".

${ }^{196}$ Ver Corte Constitucional, Auto 337/06, donde pide información sobre indicadores estadísticos existentes y propuestos para medir la magnitud del problema. El Auto 218/06 § IV.A ordena que las agencias produzcan informes en cumplimiento de órdenes judiciales anteriores sobre el caso. E1 Auto 176/05, Anexo, resume informes anteriores que solicitó a varias entidades del gobierno. Un Auto es una decisión que la Corte emite por acuerdo propio, en ejercicio de sus facultades administrativas inherentes o de su jurisdicción sobre un caso abierto. 
las entidades y redactar informes, extractos de los cuales anexa a las órdenes posteriores ${ }^{197}$. Además, igual que en el caso de la vivienda, ha realizado varias sesiones de estilo legislativo en las que participan estos grupos y las entidades administrativas relevantes ${ }^{198}$. Por último, ha flexibilizado el reglamento para dejar que terceros (en particular ONG) entablen tutelas en nombre de grupos de desplazados ${ }^{199}$. Como resultado, la Corte se ha situado a la cabeza de una coalición de instituciones gubernamentales y no gubernamentales aliadas para acopiar y sistematizar enormes cantidades de información, y para emitir más órdenes específicas cuando la acción se ha retrasado.

En su función remedial, la Corte fue más allá de señalar los principios constitucionales relevantes: impartió directrices detalladas para que las otras ramas hicieran cumplir los derechos. Igual que en el caso de las hipotecas, aquí interactuó con otros actores del gobierno, pero su labor no se ajustó al modelo dialógico clásico en el cual la Corte señala el derecho violado y deja la mayor parte del cumplimiento a las ramas políticas, en particular al legislativo ${ }^{200}$. En cambio, actuó durante largo tiempo como directivo de las entidades relevantes, y recurrió a instituciones aliadas y grupos de la sociedad civil como fuentes de información y de política. Además, no consideró al legislativo como una figura clave en sus interacciones. La Corte subrayó que no exigía una nueva legislación, y se dedicó a dictar órdenes a las entidades que tenían jurisdicción sobre el tema ${ }^{201}$. Su concepción general de la doctrina del estado de cosas inconstitucional está en armonía con su visión de que la división de poderes debe ser flexible y se debería subordinar al objetivo más importante de hacer cumplir la Constitución.

La Corte ha ideado remedios complejos y de múltiples niveles. En el nivel de generalidad más alto, ha ordenado a las entidades que

197 Ver Corte Constitucional, Auto 178/05, Anexo, que resume informes o testimonios que la Corte recibió del Fiscal General, el Defensor del Pueblo, varias asociaciones de abogados e innumerables grupos de la sociedad civil.

${ }_{198}$ Corte Constitucional, Auto 236/07, que convoca y detalla la estructura de dicha sesión. El Auto 178/05, 1-15, describe el contenido de una sesión anterior. La Corte también ha ordenado que grupos de la sociedad civil participen en la redacción de nuevos programas; ver, por ejemplo, el Auto 92/08, V.B.1.6, que ordena a las agencias la creación de nuevos programas, y les pide que "convoquen una audiencia pública participativa" antes de empezar a planificar el programa, que luego le presenten un informe que explique cómo participaron los grupos de la sociedad civil en la planificación, y que aseguren que estos grupos también intervengan en la ejecución de los programas.

199 Easterday (2008, 43).

200 Ver sección I.B.

${ }^{201}$ Ver Corte Constitucional, Sentencia T-025/04, III.10.1, donde aclara que la Corte "no está modificando la política diseñada por el Legislador". 
elaboren programas específicos (con propósitos y reglas que esboza en gran detalle) para enfrentar los problemas particulares que ocasiona el desplazamiento. Por ejemplo, hace poco ordenó la creación, en un plazo de seis meses, de un "Programa para la protección diferencial de los niños, niñas y adolescentes frente al desplazamiento forzado", con objetivos particulares, como prevenir que sean víctimas del "reclutamiento forzado por los grupos armados ilegales" y de "minas antipersonales ${ }^{202}$. A este nivel de generalidad, su objetivo es construir capacidad institucional para remediar problemas relevantes.

A nivel de generalidad medio, ha ordenado que se apliquen políticas específicas. Por ejemplo, la Corte usó la información que recibió de diversos grupos para elaborar los indicadores estadísticos necesarios para medir la magnitud del problema del desplazamiento; cuando las entidades del gobierno regresaron con propuestas de fórmulas para calcularlos, rechazó muchas de ellas y las sustituyó por las que sugerían sus aliados de la sociedad civil203. A nivel mínimo de generalidad, ha dictado numerosas órdenes para dar alivio a personas desplazadas que ha identificado. Incluso ha expedido estas órdenes para grandes grupos de demandantes. Por ejemplo, en 2008 ordenó que 1.800 niños recibieran paquetes de ayuda humanitaria en un plazo de 14 días y valoraciones individuales de sus necesidades educativas, nutricionales y psicológicas en un plazo de 3 meses 204 .

Es difícil evaluar la labor de la Corte en esta área, y aún muy pronto para ello. Pero según las opiniones de comentaristas, ONG, magistrados y funcionarios del Estado que entrevisté en agosto de 2009 sobre el caso, parece haber logrado resultados muy reales, si bien limitados. Ha habido un enorme incremento de los fondos que se dedican al problema e incrementos en otras áreas, como el porcentaje de niños desplazados que van a la escuela y reciben atención médica ${ }^{205}$. Se dispone de mejores estadísticas sobre el tamaño de la población, sus características y necesidades, y el gobierno hoy tiene una política coherente y un equipo relativamente grande trabajando en esta área. El progreso, por supuesto, ha sido muy lento, y la Corte se ha negado a utilizar mecanismos de desacato, aceptando la complejidad del problema ${ }^{206}$. Pero su enfoque ha tenido un impacto significativo.

\footnotetext{
202 Corte Constitucional, Auto 251/08, V.1.1.

203 Corte Constitucional, Auto 116/08.

204 Corte Constitucional, Auto 251/08, V.3.

205 Uprimny y Saffon $(2006,8)$ y Cepeda (2008).

206 Cepeda (1993).
} 


\section{Contrapeso del ejecutivo}

Debido a que el legislativo no actúa como un contrapeso productivo y sustantivo en la toma de decisiones del ejecutivo, la Corte ha tenido que sobrellevar gran parte de esta carga. El desarrollo de una jurisprudencia de derechos sumamente extensa le ha permitido revisar enérgicamente propuestas del gobierno, aprobadas por el legislativo o promulgadas en uso de facultades autónomas del ejecutivo. Pero aquí mi interés no es resumir su activismo general y su disposición a reconsiderar decisiones políticas del ejecutivo, una tarea que otros han emprendido ${ }^{207}$. Me ocupo, en cambio, del vínculo entre su enérgica jurisprudencia de derechos y el contexto institucional.

La Corte usa el bajo desempeño legislativo como justificación del activismo judicial cuando considera las propuestas del ejecutivo. Uno de los instrumentos básicos que usan las cortes en derecho constitucional comparado es el test de proporcionalidad o del balanceo ${ }^{208}$. En forma concisa, este instrumento sopesa los intereses que satisface una medida legislativa a la luz de los derechos y valores constitucionales que infringe. Una de las claves de cualquier test de proporcionalidad o balanceo es el nivel de deferencia con el cual se revisa la legislación, es decir, ¿con qué dureza juzga la Corte la valoración que hacen las ramas políticas de los intereses que satisface una medida legislativa particular? La pregunta es de particular importancia en un país cuya Constitución es extensa, porque prácticamente todas las medidas legislativas imponen cargas potenciales sobre algunos derechos constitucionales. La Corte colombiana ha enunciado su test de proporcionalidad de manera inusual, atendiendo a consideraciones institucionales: "Las medidas [han de ser] proporcionadas, en cuanto a los objetivos perseguidos, al cuidado de los propios debates democráticos y a los sacrificios eventualmente impuestos a los [grupos afectados]"209. En otras palabras, si el legislativo veta apropiadamente un proyecto, será deferente con las ramas políticas. Cuando no lo haga apropiadamente, hará una revisión más independiente de la propuesta del ejecutivo.

Este principio tuvo una importante aplicación en un proyecto de reforma tributaria que presentó el gobierno en 2003. E1 ejecutivo quería ampliar la base del impuesto al valor agregado (IVA), su mayor

${ }^{207}$ Para una visión general del activismo de la Corte en asuntos de derechos, ver Cepeda (1993); ver también las notas 118-120, que describen algunos casos claves.

${ }^{208}$ Weinrib $(2006,96)$ menciona la proporcionalidad como parte del "paradigma de posguerra" en derecho constitucional en todo el mundo.

${ }^{209}$ Corte Constitucional, Sentencia C-038/04 § VII.27, cursivas añadidas.

Revista de Economía Institucional, vol. i3, n. ${ }^{\circ}$ 24, Primer semestre/2oit, pp. i3-83 
fuente de recursos, gravando muchos productos tradicionalmente exentos. La crisis fiscal empeoró cuando el proyectó estaba en el Congreso, lo que llevó al presidente a ampliarlo proponiendo gravar un grupo de productos históricamente exentos por el hecho de ser “de primera necesidad". La principal crítica a la ley se basó en el argumento de que infringía inconstitucionalmente el derecho a la vida y a la subsistencia al elevar el precio de los bienes de primera necesidad de personas carentes de recursos ${ }^{210}$.

La Corte empezó señalando que, en principio, al Congreso se le había atribuido un "amplio margen de configuración de la política tributaria" ${ }^{211}$. El problema era la calidad del debate sobre las medidas en cuestión. Después subrayó que las medidas no fueron objeto de "un mínimo de deliberación pública en el seno del Congreso sobre [sus] implicaciones a la luz de los principios de progresividad y equidad" Señaló que la ampliación del IVA no estaba en el proyecto original sino que era una adición presidencial de último minuto, inducida por el deterioro de la situación fiscal a lo largo del año ${ }^{213}$. En la revisión de los registros del Congreso encontró que no se había tratado esta parte del proyecto. De modo que nunca se discutieron las consecuencias de la medida para la clase media y los estratos pobres, limitándose a estampar la rúbrica en la propuesta presidencial ${ }^{214}$. Además, en el proyecto se observó una ampliación "indiscriminada" de la base para incluir muchos artículos dispares, lo que indicaba falta de deliberación ${ }^{215}$.

En vista de estos hechos, la Corte encontró que el legislativo no había cumplido su función adecuadamente; por ello no le daría un "margen de configuración" ${ }^{16}$. En cambio, revisó independientemente la ley a la luz del derecho constitucional a la vida y la declaró inexequible, influida por el contexto de reducción del gasto social, alta evasión de impuestos por parte de los ricos, y porque mucho del nuevo gasto se destinaría a defensa y seguridad y no a programas sociales ${ }^{217}$.

Esta línea doctrinal es una vía mejor para vindicar los intereses que la Corte ha identificado en su jurisprudencia sobre el procedimiento legislativo ${ }^{218}$. Igual que en esos casos, le preocupa que el legislativo actúe sin suficiente "deliberación” y que "la autonomía del Congreso"

${ }^{210}$ Corte Constitucional, Sentencia C-776/03.

${ }^{211}$ Ibíd., § VIII.4.5.0.

${ }^{212}$ Ibíd.

${ }^{213}$ Ibíd., VIII.4.5.6.1, donde observa que la propuesta obedeció “a la necesidad de atender requerimientos fiscales no previstos originalmente en dicho proyecto".

${ }^{214}$ Ibíd.

${ }^{215}$ Ibíd., § VIII.4.5.7.

${ }^{216}$ Ibíd., § VIII.4.5.6.1.

217 Ibíd., § VIII.4.5.

${ }^{218}$ Ver sección III.B. 
sea vulnerada por duras tácticas presidenciales durante el proceso legislativo ${ }^{219}$. Pero el enfoque es menos formalista; la Corte puede dar más atención a la sustancia del debate y no tanto al cumplimiento de algunas de sus etapas ${ }^{220}$. Y su remedio, cuando detecta problemas, es revisar en forma independiente la política del ejecutivo y no declarar automáticamente inexequible el proyecto por razones de procedimiento. Además, es flexible; en esas (raras) ocasiones en que el Congreso hace un examen exhaustivo de un proyecto presidencial, la Corte es más deferente ante la decisión política ${ }^{221}$. Así mantiene abierta la capacidad del Congreso para desarrollar un constitucionalismo legislativo y le da incentivos para ello.

\section{LA CORTE COLOMBIANA EN PERSPECTIVA COMPARADA: HUNGRÍA Y SURÁFRICA, MENORES GRADOS DE ACTIVISMO}

Es difícil apreciar el peso de la carga que el contexto institucional colombiano impone a la Corte sin comparar su labor con la de otras

219 Corte Constitucional, Sentencia C-776/03 § 4.5.6; ver también ibíd. § 4.5.3.2.1, la "deliberación hace efectivo el principio de representación política, puesto que traduce la posición de los representantes del pueblo, expresada en razones públicas por todos conocidas o, al menos, identificables".

${ }^{220}$ En este sentido, la labor de la Corte se parece a la recomendación de los teóricos estadounidenses que apoyan una consideración estricta de las deliberaciones del legislativo para asegurar que sean suficientemente racionales y no se basen en fundamentos prohibidos. Cass Sunstein (1985, 69-73) pide una revisión de racionalidad más intensa para determinar si el Congreso realmente consideró una justificación pública de su proyecto, y un análisis más minucioso del registro del Congreso para asegurar que las leyes realmente no se basan en prejuicios contra grupos desfavorecidos.

${ }^{221}$ Un caso de 2004 relacionado con profundas reformas orientadas a flexibilizar las leyes laborales muestra la otra cara de la doctrina en esas raras ocasiones donde la Corte encuentra que el legislativo ha tenido buen desempeño. Bajo su propia jurisprudencia anterior, estas medidas (facilitar los despidos, reducir las pensiones, permitir reducciones de salarios) eran problemáticas porque afectaban la seguridad económica de los estratos medio y bajo. En general, conforme a su principio de "progresividad" en el área socioeconómica, el Estado no puede empeorar la situación de los grupos más pobres mediante cambios de política (Uprimny y Guarnizo, 2006, 7-11, 14). Así, la Corte encontró que había un caso de inconstitucionalidad prima facie. Pero observó, inusualmente, que el legislativo había "estudiado y justificado cuidadosamente" las medidas, y dio deferencia al criterio del legislativo (Sentencia C-038/04 § VII.25). Ver ibíd., § VII.32, donde discute el concepto de deferencia con el legislativo en asuntos diferentes, en otros temas, incluidos asuntos económicos empíricos, y $\S$ VII.36, donde da deferencia a la decisión adoptada en el proceso legislativo. La Corte señaló, por ejemplo, que las ponencias mayoritarias sometidas a debate estudiaban los asuntos "detalladamente" y hacían "amplias presentaciones teóricas y empíricas destinadas a defender la tesis básica que sustenta la reforma laboral" (ibíd., VII.33 y VII.35). Además, indicó que si bien la propuesta de reformar las leyes laborales se había originado en el ejecutivo, grandes porciones del contenido final del proyecto provenían realmente del proceso legislativo (ibíd., § VII.35). 
cortes importantes. En esta sección comparo brevemente su trabajo con el de dos cortes constitucionales que han sido cubiertas extensamente por la literatura sobre derecho constitucional comparado: la Corte Constitucional húngara y la Corte Constitucional surafricana. Se considera que ambas son sumamente "activistas" porque suelen intervenir comúnmente en asuntos sociales y políticos importantes. Pero ninguna de ellas ha asumido el papel de la Corte colombiana. Argumento que las diferencias se deben al contexto institucional. La Corte húngara desempeñó tareas similares a las de la Corte colombiana en los años noventa pero redujo su activismo debido a rápidas mejoras de la calidad de las instituciones democráticas. La Corte surafricana cumple un papel importante en la política democrática pero es mucho más deferente con las ramas elegidas. En un sistema de partido único, donde existen fuerzas políticas coherentes, ese papel es posible y más apropiado. En cambio, en Colombia, donde los partidos políticos son incoherentes y hay pocas perspectivas de rápido mejoramiento de la calidad de las instituciones democráticas, la Corte se ha visto forzada a desempeñar un rol altamente intervencionista durante un periodo indefinido.

\section{A. LA CORTE HÚNGARA: ACTIVISMO TEMPORAL}

En los años noventa la Corte húngara realizó tareas similares a las que emprendió la Corte colombiana, pero su labor tuvo menor duración. Aunque después de la caída del comunismo no había una cultura constitucional en Hungría y las instituciones representativas actuaban de manera deficiente, la situación mejoró rápidamente en los noventa. El contexto - de transición de un régimen totalmente autoritario- hizo posibles las perspectivas de rápido mejoramiento del desempeño de las instituciones democráticas. En contraste, la Corte colombiana fue creada en el contexto de una democracia de larga duración pero que funcionaba de manera deficiente -con instituciones democráticas problemáticas-, y estos problemas no han desaparecido desde su creación. A diferencia de Hungría, no hay una dimensión temporal obvia para el activismo de la Corte colombiana.

Cuando Hungría hacía la transición a la democracia a finales de los años ochenta y comienzos de los noventa, su sistema de partidos era débilmente institucionalizado. En el período comunista no había partidos y los grupos de la sociedad civil eran débiles ${ }^{22}$. En forma poco sorprendente en ese contexto, las organizaciones que empezaron a surgir a finales de los años ochenta eran simples vehículos de

222 Ilonszki (1998, 158-159).

Revista de Economía Institucional, vol. I3, n. ${ }^{\circ} 24$, Primer semestre/2oir, pp. i3-83 
individuos en busca de cargos; estos individuos estaban unidos por su oposición al régimen comunista y no por posiciones políticas comunes ni por el objetivo de representar a un grupo social distinto ${ }^{223}$. En otras palabras, estos primeros partidos eran "organizaciones formadas por élites" que "rara vez se construían sobre delimitaciones claras" ${ }^{224}$. A menudo carecían de plataformas ideológicas, y las vagas plataformas que existían se modificaban con frecuencia ${ }^{225}$. La estructura interna de los partidos era tan subdesarrollada que, en palabras de un analista, "desafiaba el estudio sistemático" 226 . Los vínculos entre los partidos y los grupos de la sociedad civil eran débiles. Los partidos no tenían lazos con sindicatos, gremios de empresarios u otras organizaciones, y en este sentido las instituciones elegidas se "construían sobre arena"227. La disciplina de partido era relativamente baja en los años noventa: el 14\% de los legisladores elegidos para el primer parlamento cambió de partido después de ser elegido ${ }^{228}$. En ese contexto, el Parlamento se comportó incoherentemente en sus primeros años. Tenía problemas para tomar decisiones sobre algunas medidas importantes y sus políticas a menudo no reflejaban la voluntad de la mayoría ${ }^{229}$. Por ejemplo, a comienzos de los noventa el primer gobierno dedicó una cantidad de tiempo desmesurada a debatir asuntos como el escudo nacional en vez de tratar las graves dificultades estructurales del país ${ }^{230}$. El problema se combinaba con la falta de cultura constitucional o de tradición constitucional en el país; los políticos no daban importancia ni hacían esfuerzos para materializar una visión constitucional clara.

La incoherencia de la política húngara abrió la posibilidad para que la judicatura labrara un papel sustancial para sí misma, y esta posibilidad se reforzó con las sólidas facultades de la Corte, que rivalizan con las de la Corte colombiana. La Corte húngara, igual que la colombiana, está facultada para atender "acciones populares" o peticiones de revisión abstracta que presente cualquier individuo, así como demandas de constitucionalidad de actos particulares de las autoridades ${ }^{231}$. De acuerdo con Kim Lane Scheppele, el país se convirtió en una "legislocracia": a mediados de los años noventa,

${ }^{223}$ Ibíd., 159.

${ }^{224}$ Ibíd.

${ }^{225}$ Ibíd., 164-165.

${ }^{226}$ Racz y Kukorelli $(1995,262)$.

227 Scheppele $(2005,33)$.

${ }_{228}$ Olson $(1998,435)$.

${ }^{229}$ Scheppele $(2005,35-36)$.

${ }^{230}$ Ibíd., 40.

${ }^{231}$ Schwartz (2000, 77-79), en ibíd., 75, dice que la Corte es "por diseño y función [...] la más poderosa de Europa Oriental". 
"para todos los efectos, la Corte Constitucional gobernaba el país”232. La Corte declaró inexequible cerca de la tercera parte de las leyes demandadas en los primeros años, y en muchas áreas importantes de política reescribió por completo los programas ${ }^{233}$.

Más allá del poder absoluto de la Corte húngara en los noventa, comparable al de la Corte colombiana, hay algunos aspectos claves donde la jurisprudencia de las dos cortes era similar. Primero, la jurisprudencia de la Corte húngara reflejaba la concepción de sí misma como institución dedicada a desarrollar un programa constitucional y asegurar de ese modo la transformación social, y no una concepción basada en las limitaciones de su papel. Tenía un claro sentido de misión -su jurisprudencia, por ejemplo, se centraba primordialmente en el recurso a la dignidad humana para modificar la concepción del Estado de la época comunista como presencia ubicua en la vida privada de los ciudadanos ${ }^{234}$. Segundo, igual que la Corte colombiana, la Corte húngara introducía política en el sistema, valiéndose de la facultad para declarar una situación "inconstitucional por omisión" y ordenando al parlamento la expedición nuevas leyes. En sus primeros años, la Corte usó esta facultad para forzar la promulgación de nuevas leyes que protegieran el medio ambiente y aseguraran que los medios de comunicación fueran pluralistas y libres del control del gobierno ${ }^{235}$.

Finalmente, igual que la Corte colombiana, la Corte húngara era activa en asuntos socioeconómicos, y gran parte de su trabajo se dedicó a proteger a la clase media y no a los más pobres. La historia es similar en ambos países: el país afronta una crisis económica, pero las instituciones domésticas no dan respuesta debido a la presión internacional para que tomen medidas de austeridad y porque los partidos tienen débiles vínculos con el público ${ }^{236}$. En Hungría, la crisis económica de 1995 llevó a que el gobierno redujera el gasto

${ }^{232}$ Scheppele $(2005,44)$.

233 Ibíd.

${ }^{234}$ Ver, p. ej., la Decisión 15/1991 (13 de abril de 1991), en Solyom y Brunner (2000, 139), que declara ilegal que el Estado use un número de identificación unificado para vigilar a los ciudadanos. La Decisión 8/1990 (23 de abril de 1990), ver ibíd., 105, declara inexequible una ley de la época comunista que permitía que los sindicatos representaran a quienes no eran miembros por ser contraria a los derechos de autodeterminación básicos. Dupré (2003) describe el uso que hace la Corte húngara de la dignidad humana como un "derecho madre".

${ }^{235}$ La Decisión 28/1994 (20 de mayo de 1994), ver Solyom y Brunner (2000, 298), ordena al Congreso que expida leyes de protección del medio ambiente. La Decisión 37/1992 (10 de junio de 1992), ver ibíd., 239, le ordena que expida leyes que aseguren que ni el Estado ni otros grupos de interés tengan impacto desproporcionado en los medios de comunicación.

${ }^{236}$ Scheppele (2004, 1941-1949) explica la crisis en Hungría. 
social en rubros como la atención infantil, las incapacidades por enfermedad y el seguro social. En un Estado subdesarrollado y postcomunista como Hungría, la mayor parte de ese gasto iba a trabajadores de clase media y no a grupos marginados ${ }^{237}$. En sus decisiones, la Corte húngara permitió algunos recortes pero denegó muchos otros, subrayando en general el concepto de "seguridad jurídica”, que impide que el Estado reduzca drásticamente los beneficios de alguien en el muy corto plazo ${ }^{238}$. Aunque algunos comentaristas han criticado esta línea de decisiones por desarrollar derechos sociales de grupos que no lo necesitaban desesperadamente $^{239}$, otros han señalado que, así como en Colombia, la defensa de los derechos sociales en nombre de estratos de clase media (realmente muy pobres según la mayoría de los indicadores) tiene cierta lógica democrática en un sistema político que funciona mal ${ }^{240}$. En dicho sistema, la Corte puede ser la rama de gobierno que produce las políticas más mayoritarias.

La diferencia principal entre las cortes colombiana y húngara es simplemente que el contexto institucional húngaro experimentó un rápido cambio en los años noventa mientras que el contexto colombiano ha estado estancado o ha empeorado desde 1991. Los partidos húngaros maduraron rápidamente en los primeros años de democracia y hoy están entre los más fuertes de Europa Oriental ${ }^{241}$. La identidad de los partidos ha sido estable, y los partidos han logrado forjar identidades más coherentes y vínculos más fuertes con grupos de la sociedad civil $^{242}$. Seguir el curso de la difusión de los valores constitucionales es mucho más difícil, y el proceso es inevitablemente lento, pero los comentaristas argumentan que, en gran parte debido a la labor de la

237 Ibíd.

${ }^{238}$ La Decisión 43/1995 (el 30 de junio de 1995), ver Solyom y Brunner (2000, 322), extracta una de las decisiones de la Corte sobre el paquete de austeridad. Scheppele (2004, 1945-1949) explica estas decisiones en algún detalle.

239 "En Hungría, los derechos sociales se entendían como derechos de la abrumadora mayoría. En estas circunstancias, el cumplimiento judicial de los derechos sociales no se puede considerar contra-mayoritario, aunque yo argumentaría que las soluciones mayoritarias prevalecientes eran ineficaces y socialmente injustas. A diferencia de la Corte Suprema india, la protección de derechos sociales de la Corte Constitucional húngara nunca se ha dirigido a proteger los derechos de los más necesitados contra un gobierno alienado y no receptivo" (Sajó, 2006, 97).

240 "Cuando los nuevos gobiernos empezaban a parecerse al gobierno de la época comunista en la manera de tratar a la ciudadanía [...] la Corte Constitucional húngara entraba en acción [...] Su labor era proteger la democracia protegiendo la capacidad de los ciudadanos para hacer oír su voz en el gobierno" (Scheppele, 2005, 51).

${ }^{241}$ Olson $(1998,463)$ y Toole $(2000,455-456)$.

${ }^{242}$ Ágh (1995) explica la forma en que el Partido Socialista Húngaro desarrolló una plataforma relativamente clara y creó vínculos con grupos de la sociedad civil. 
Corte, algunas normas claves relacionadas con la privacidad y con la autonomía del mercado se han afianzado entre los actores políticos y el público en general ${ }^{243}$. A finales de los años noventa desapareció la necesidad de una Corte muy activista, y la nueva Corte que se nombró alrededor de 1998 estaba compuesta por jueces mucho menos activistas. La Corte después ha cumplido a veces un papel clave en la política húngara, pero nunca retornó a algo semejante a la "legislocracia" de los primeros años ${ }^{244}$. Se ha dado un espacio bastante abierto para que funcionen otras instituciones democráticas.

No pretendo argumentar que el "refrenamiento" de la Corte húngara que ocurrió en 1998 fue totalmente benéfico; los problemas reales continuaron en la democracia húngara, y es posible que el péndulo del poder judicial oscile demasiado lejos en la otra dirección, también con mucha rapidez ${ }^{245}$. El modelo básico de activismo judicial temporalmente limitado en los primeros años de una nueva democracia estuvo disponible en Hungría y puede estarlo en muchas sociedades en transición. Pero no así en países como Colombia que han sido democracias de baja calidad por largo tiempo. Sería problemático reducir el fortísimo papel de la Corte colombiana en la política nacional hasta que mejore el desempeño de otras instituciones políticas; algo que es improbable que ocurra en el corto plazo.

\section{B. LA CORTE SURAFRICANA: ACTIVISMO LIMITADO POR EL DiÁlOGO Y LA DEFERENCIA}

La principal diferencia entre las experiencias húngara y colombiana es el carácter transitorio de la labor de la Corte húngara, durante la transición de un régimen autoritario. La principal diferencia entre las experiencias colombiana y surafricana es la forma en que la Corte surafricana se relaciona con otras instituciones políticas. La Corte surafricana ha intentado inyectar ciertos debates políticos en el sistema pero de una manera que respeta el rol deliberativo del Parlamento. En contraste, la Corte colombiana (como la Corte húngara en los años noventa) ha ido mucho más lejos y a menudo ha ordenado acciones específicas a otras ramas políticas. Además, la Corte surafricana generalmente ha concordado con los proyectos básicos de las ramas políticas y sólo los ha cuestionado cuando han ido demasiado lejos en el ataque a grupos con poca representación o cuando han reflejado poca deliberación ${ }^{246}$. Es claro que la Corte surafricana no rige el país

${ }^{243}$ Ver Schwartz $(2000,107)$.

${ }^{244}$ Halmai $(2007,1)$.

${ }^{245}$ Scheppele (2005, 53-54).

${ }^{246}$ Ver Roux $(2009,138)$, quien manifiesta que la Corte surafricana ha forjado 
de la forma en que lo hizo la Corte húngara ni de la manera como hace la Corte colombiana de vez en cuando.

Este rol más limitado pero esencial se ajusta al contexto político: el problema de la política surafricana no es la existencia de partidos débiles e incoherentes sino la existencia de un partido dominante, el Congreso Nacional Africano (CNA), que se ha mantenido en el poder desde el fin del apartheid ${ }^{247}$. Este partido tuvo una influencia preponderante en la redacción de la Constitución del país luego del apartheid y comparte la misión general de transformación social que está en la base de ese documento ${ }^{248}$. Por tanto, en vez de enfrentarse a fuerzas políticas incoherentes que ignoran la Constitución, la Corte surafricana tiene en las ramas políticas, al menos en un grado limitado, a un socio en el desarrollo constitucional. Como ya señalé, este tipo de sistemas de partido único crea graves problemas a la democracia, y Suráfrica no es una excepción ${ }^{249}$. Aunque el CNA es una amplia coalición de intereses, su incentivo y su capacidad para representar a ciertos grupos minoritarios, como la minoría blanca, a veces suscitan escepticismo ${ }^{250}$. Además, el proceso de negociación dentro del partido puede haber marginado a ciertos intereses e ideologías ${ }^{251}$. Finalmente, existe un riesgo real de que la concepción del proyecto de transformación constitucional que tiene el CNA se desvíe en diversos puntos o se centre por completo en prioridades ampliamente representadas en el partido (como superar los prejuicios raciales), excluyendo otros valores constitucionales (como la reducción de la pobreza) ${ }^{252}$. En otras palabras, la falta de competencia política puede llevar a que la cultura constitucional se desarrolle de maneras que no respeten plenamente el espíritu del texto constitucional.

una relación muy estrecha con el CNA.

${ }^{247}$ Para estudios del contexto político sudafricano, ver Lanegran (2002), Giliomee (1998) y Giliomee et al. (2001).

${ }^{248}$ Berat $(2005,42-43,56)$ señala que el CNA dominó en las elecciones a la asamblea constituyente que redactó la constitución interina y al parlamento que produjo la constitución final.

${ }^{249}$ Ver sección I.A.3.

${ }^{250}$ Giliomee et al. $(2001,167)$ sostienen que "el CNA no necesita ganar votos de la minoría blanca y la puede tratar con indiferencia o desprecio", y que "la nueva democracia trabaja principalmente para la mayoría racialmente definida".

${ }^{251}$ Ver ibíd. (172-173) donde se argumenta que el CNA ha reprimido la disensión dentro del partido. Friedman (1999, 106-107) describe casos en que la jefatura del partido ha reprimido a grupos disidentes del partido.

${ }^{252}$ Giliomee $(1998,134-137)$ observa que las políticas del CNA se centran en "desigualdades estrechas entre negros y blancos, y tienden a beneficiar a la clase media negra, en vez de ocuparse de asuntos de desigualdad entre clases que beneficiarían a los más pobres. Simkins (1999, 58-59) argumenta que, por razones políticas, el CNA puede centrar la atención en la redistribución del poder de la clase media blanca a la clase media negra en vez de aliviar la pobreza. 
La asociación general entre la Corte y el CNA es evidente en su jurisprudencia sobre acción afirmativa y políticas similares. Como argumenta Theunis Roux, ha actuado básicamente para "legitimar la transformación" en estas áreas; ha respaldado la mayoría de los esfuerzos del CNA para redistribuir el poder de los ciudadanos blancos entre ciudadanos negros y ha contribuido a legitimar esos esfuerzos justificando por qué son congruentes con los objetivos constituciona$\operatorname{les}^{253}$. En una serie de casos, ha respaldado los intentos de redistribuir dinero y personal de escuelas antes favorecidas (es decir, blancas) a escuelas antes desfavorecidas (es decir, negras) ${ }^{254}$. Pero al mismo tiempo, ha tratado de dar alguna protección a grupos excluidos. En los casos de las escuelas, protegió los derechos de estudiantes blancos reconociéndoles el derecho a una notificación oportuna antes de terminar la ayuda financiera ${ }^{255}$. El rol básico de la Corte en esta área ha sido el de permitir que el CNA formule la política y luego hacer una revisión limitada de la racionalidad y la justicia de esa política en beneficio de grupos políticamente débiles.

La Corte surafricana también ha introducido política en el orden político cuando ha considerado que el CNA es demasiado selectivo en su visión de la transformación constitucional. Pero incluso en esos casos ha abordado la tarea de manera diferente a la Corte colombiana debido a diferencias en el contexto político. Mientras que la Corte colombiana ha actuado como gerente de política en diversos asuntos, la Corte surafricana generalmente ha optado por definir un derecho y ordenar a las ramas políticas que actúen a ese respecto. Muy raras veces les ha dicho qué deben hacer exactamente ${ }^{256}$. El famoso caso "Gobierno de la República de Sudáfrica contra Grootboom" es emblemático de este modelo dialógico clásico ${ }^{257}$. En este caso falló que el

${ }^{253}$ Roux (2004, 92); ver también Dugard y Roux (2006, 107), que exponen un argumento similar.

${ }_{254}$ Ver Premier, Mpumalanga v. Executive Comm. Ass'n of Governing Bodies of State-Aided Schools: E. Transvaal, 1999 (2) SA 83 (CC), donde determinó que, en general, la supresión de la ayuda a los estudiantes de escuelas blancas ricas era permisible, aunque declaró inexequible la medida por la falta de notificación. En Bel Porto School Governing Body v. Premier of the Province, W. Cape, 2002 (9) BCLR 891 (CC), determinó que el gobierno podía trasladar fondos para gastos de personal de las escuelas blancas tradicionalmente favorecidas a las escuelas negras desfavorecidas.

2551999 (2) SA 83 (CC).

${ }^{256}$ Roux $(2009,133-136)$ destaca la preferencia de la Corte por pruebas vagas y remedios deferenciales para preservar su legitimidad con el CNA. Woolman (2007, 762) argumenta que la Corte no ha hecho lo suficiente para dar un contenido claro a las cláusulas constitucionales.

257 2001(1) SA 46. Existen numerosos comentarios sobre este caso famoso. Para algunas discusiones recientes, ver Tushnet (2008, 242-244), Dugard y Roux (2006, 113-116), Berat (2005, 66-68), Kende (2003, 142-145) y Sachs (2005). 
plan del gobierno para financiar vivienda social era inconstitucional porque no había considerado a personas como el demandante, que carecían de vivienda por ser indigentes ${ }^{258}$. Una manera de ver el caso es que la Corte le dijo al CNA que su "lectura" de la Constitución se fijaba excesivamente en consideraciones raciales y descuidaba la protección de los indigentes. La estrategia política del CNA a menudo se centra en la distribución del poder a la clase media negra y a estratos más bajos mientras que ignora a las clases políticamente más débiles y más pobres ${ }^{259}$. La Corte elogió los lineamientos generales del plan del gobierno pero argumentó que la falta de apoyo a los indigentes no era razonable ${ }^{260}$.

No obstante, no dio alivio específico al demandante ni dijo al gobierno qué tipo de plan adoptar. Sentenció que la Constitución "obliga al Estado a diseñar y ejecutar un plan coherente y coordinado" y que se debía destinar "una parte razonable del presupuesto nacional de vivienda" a la población indigente, pero no hizo ningún esfuerzo para dar contenido a esos términos ${ }^{261}$. Aunque se ha planteado que el caso Grootboom es una forma universalmente aplicable de hacer cumplir los DESC ${ }^{262}$, es más apropiado verlo como un plan de ataque condicionado institucionalmente. No habría tenido sentido en $\mathrm{Co}^{-}$ lombia o en Hungría en los años noventa, porque las instituciones políticas no estaban suficientemente desarrolladas para entablar este tipo de diálogo. El diálogo exige un nivel de coherencia del sistema de partidos y de las instituciones políticas que rara vez existe en el mundo en desarrollo. Las cortes húngara y colombiana interactúan con otras ramas del gobierno, pero son mucho más activas en decirles qué hacer exactamente.

No quiero dar a entender que el modelo surafricano sea ajeno a todo reproche, más que el modelo húngaro. Es posible que fallos como el del caso Grootboom no sean suficientemente robustos para lograr

${ }^{258}$ Government of the Republic of South Africa v. Grootboom, 2001(1) SA 79.

259 “Aunque el CNA llegó al poder prometiendo aliviar las penurias de los negros pobres, los grupos más destacados en la política del gobierno son los trabajadores sindicalizados y la clase media negra, bien sean empleados privados o funcionarios públicos" (Giliomee, 1998, 134-136).

260 "Lo que se ha hecho en la ejecución de este programa es un gran logro. Se han gastado grandes sumas de dinero y se ha construido un alto número de viviendas" (2001 [1] SA 76).

${ }^{261}$ Ibíd. $(79,86)$. La Corte también decidió que el plan tenía que "asegurar que se dé alivio al mayor número de indigentes, aunque no todos necesiten recibirlo inmediatamente".

${ }^{262}$ Tushnet $(2008,242-244)$ cataloga el caso Grootboom como una "revisión judicial de forma débil", un método promisorio para hacer cumplir los DESC. Sunstein $(2001,221-222)$ considera que en este caso se adoptó un modelo administrativo de cumplimiento de los DESC que se podría usar en otras partes. 
cambios reales aunque se enfrenten fuerzas políticas coherentes y en general amigables ${ }^{263}$. También es posible que la Corte no haya hecho lo suficiente para defender los intereses de grupos excluidos de la coalición del $\mathrm{CNA}^{264}$. La Corte también puede estar ideológicamente muy cerca del CNA, o su necesidad de supervivencia puede limitar demasiado sus acciones ${ }^{265}$. Mi punto aquí es más modesto: la labor de la Corte se ha de evaluar en su contexto político. Muchas acciones judiciales que son razonables en Colombia no tendrían sentido en Suráfrica y viceversa. La configuración exacta de las instituciones políticas en Colombia le ha impuesto a su Corte la carga extraordinaria de asumir un papel activista en la democracia, el cual no está limitado por la duración (Hungría) ni por el alcance o el estilo (Suráfrica). En la conclusión se evalúan las contribuciones de la Corte a la democracia colombiana en un intento de avanzar hacia una teoría del rol judicial que se ajuste al derecho constitucional comparado.

\section{CONCLUSIÓN: HACIA UNA TEORÍA DEL ROL JUDICIAL EN LAS NUEVAS DEMOCRACIAS}

En este artículo se presentan dos argumentos principales. E1 primero es que la teoría constitucional estadounidense es una exportación problemática en derecho constitucional comparado porque se basa en supuestos sobre las instituciones políticas que a menudo no se cumplen en los países en desarrollo. En particular, la idea de que hay clara una división entre el "rol legislativo" y "el rol judicial", construida sobre fundamentos justificables normativamente, no se puede trasladar a gran parte del mundo en desarrollo. No obstante, la teoría constitucional de estos países sigue usando tropos derivados de esa teoría. Las críticas a las decisiones de la Corte Constitucional colombiana en la crisis hipotecaria son ilustrativas y familiares desde la experiencia constitucional de Estados Unidos. Una importante

${ }^{263}$ Roux $(2002,41)$ argumenta que la Corte debería haber dicho más claramente lo que debían hacer los actores políticos. "E1 alivio concedido debería haber sido adecuado para dar sustancia a los derechos específicos que la Corte detectó en cada caso" (Berat, 2005, 71-72). En casos más recientes, las altas cortes parecen haber quedado frustradas por el ritmo del cambio en el tema de vivienda y han intentado ir más allá del caso Grootboom involucrando a la sociedad civil (Ray, 2009).

${ }^{264}$ Roux (2009, 125-130) menciona varios casos en que la Corte "se comprometió con un principio" pero no protegió a la parte minoritaria.

${ }^{265}$ Roux (ibíd., 136-138) dice que en razón del régimen de partido dominante, la Corte debe seguir una línea fina entre "principios" y "pragmatismo" en sus acciones. "Se sabe que se escogieron cuidadosamente magistrados que respaldaban al CNA, o, como mínimo, simpatizantes de los movimientos de liberación" (Berat, 2005, 74). 
línea de críticas se centró en la legitimidad de su labor: los críticos argumentaron que la Corte estaba empeñada en "una subjetiva ponderación entre costos y beneficios cuyo resultado le corresponde a los [funcionarios] elegidos" ${ }^{266}$. Otro ataque se centró en su capacidad: los asuntos económicos "son complejos y cuando [...] se deban alterar es mejor que lo haga el Congreso" 267 . La extrañeza de estas críticas es que la visión del legislativo es abstracta y formalista y no se basa en la realidad colombiana: ignoran las débiles credenciales democráticas y la baja capacidad del Congreso colombiano.

Estas críticas tampoco consideran la posibilidad de que la Corte colombiana esté desarrollando una capacidad institucional y una legitimidad democrática que van mucho más allá de la historia estándar de las cortes. Ya comenté las características que hacen posible que la Corte acopie información: el acceso relativamente libre de los ciudadanos a la Corte mediante la acción de tutela ${ }^{268}$, sus estrechas alianzas con grupos de la sociedad civil ${ }^{269}$ y su disposición a realizar audiencias de estilo legislativo ${ }^{270}$ le han ayudado a obtener información bastante precisa sobre los problemas sociales. Además, sus alianzas con algunas instituciones afines creadas por la Constitución de 1991 (como el Defensor del Pueblo) y con grupos de la sociedad civil le han dado éxito en el manejo de complicadas iniciativas de política, como durante el litigio de los desplazados 271 .

E1 orden institucional también ha llevado a que la Corte sea menos antidemocrática de lo que insinúan los críticos, aunque esto genere controversia. La Corte colombiana está constantemente bajo la amenaza de las élites políticas, y su baluarte más sólido contra esa amenaza es su red de aliados de la sociedad civil y, así como sucedió con la Corte húngara en los años noventa, su muy alta popularidad institucional. Puesto que para su protección institucional la Corte parece depender de la popularidad y no de las relaciones con las élites políticas, puede reflejar bastante bien la voluntad democrática. En efecto, decisiones como la del caso de los intereses de las hipotecas ${ }^{272}$ indican que la Corte hace una mejor labor que cualquiera de las otras ramas para responder al clamor popular. A diferencia de Estados Unidos, donde los constitucionalistas populares argumentan que el reclamo de la supremacía judicial en la interpretación constitucional

\footnotetext{
${ }^{266}$ Clavijo (2001).

267 Ibíd.

${ }^{268}$ Ver el texto que acompaña a la nota 195.

${ }^{269}$ Ver el texto que acompaña a las notas 182, 196-197.

${ }^{270}$ Ver el texto que acompaña a las notas $180,198$.

${ }^{271}$ Ver el texto que acompaña a las notas 196-197.

${ }^{272}$ Ver sección III.C.1.
} 
es un obstáculo para el desarrollo del constitucionalismo a través del Congreso y del pueblo ${ }^{273}$, en Colombia la Corte parece ser el mejor reflejo de la opinión popular sobre la transformación constitucional. La voluntad y la capacidad del legislativo colombiano para llevar a cabo esta transformación, en cambio, son muy limitadas.

Por tanto, es necesario replantear el concepto de la independencia judicial en la política constitucional comparada ${ }^{274}$. En vez de considerar únicamente si una corte está aislada de otros actores, puede ser mejor centrarse en aquellos que la corte considera sus electores y en cómo afectan estos vínculos su funcionamiento y su legitimidad. Por ejemplo, Roux sostiene que la Corte surafricana creó vínculos estrechos con el CNA y habitualmente ignora al público en general porque no depende de él para su supervivencia ${ }^{275}$. Las cortes colombiana y húngara muestran el patrón opuesto: en un contexto de fuerzas políticas incoherentes, ambas eligieron forjar vínculos más sólidos con elementos del público general que con las élites políticas. En todos los casos, lo que a primera vista parecería una debilidad de estas cortes -su relación con actores no judiciales- puede ser realmente una fortaleza porque aumenta su legitimidad democrática. Al mismo tiempo, los diferentes tipos de vínculos producen diferentes tipos de jurisprudencia: la función de legitimación de la Corte surafricana y el gentil pero productivo llamado de atención al CNA es un tipo de labor bastante diferente de los intentos húngaro y colombiano de manejar grandes porciones de la política del Estado.

El segundo argumento central es que el análisis comparado de las instituciones políticas puede ayudar a orientar el desarrollo de las teorías del rol judicial. Mi análisis comparado de Colombia, Hungría y Suráfrica sugiere que las diferencias entre sistemas de partidos no institucionalizados y sistemas de un partido dominante pueden tener gran impacto en el papel que las cortes deberían cumplir en las nuevas democracias. La comprensión de las grandes diferencias de las instituciones políticas no nos da respuestas claras sobre lo que deberían hacer las cortes, pero ayuda a hacer las preguntas que deberíamos hacer.

${ }^{273}$ Ver Tushnet (1999) y Kramer (2004).

274 Para ejemplos de la literatura sobre la independencia judicial y su importancia, ver Finkel (2008), Helmke (2005), Ramseyer y Rasmusen (2003) y Stephenson (2003).

275 "Aunque las encuestas sociales sugieren que la Corte no disfruta de mucho apoyo público, este hecho se puede atribuir al carácter peculiar de la política surafricana, en la que un partido político dominante libera a la Corte Constitucional surafricana de la necesidad de atraer a la opinión pública” (Roux, 2009, 107). 
Como señala Roux, la primera pregunta en teoría comparada del rol judicial se relaciona con la supervivencia ${ }^{276}$. No siempre podemos disculpar las acciones de una corte porque eran necesarias para asegurar su supervivencia, pero criticaríamos a una corte que rutinariamente emprenda acciones autodestructivas. Y, como indica Roux, las instituciones políticas cumplen un papel significativo en la definición del tipo de acciones que aseguran la supervivencia de la rama judicial ${ }^{277}$. La Corte surafricana, en un orden político dominado por el CNA, no tiene otra elección que mantener una relación cercana con el partido; la Corte colombiana, en un orden político incoherente, no tiene otra elección que mantener un alto nivel de respaldo público. Pero la búsqueda de supervivencia no agota el tema, y más allá de este aspecto central, se hace más difícil discernir lo que deberían hacer las cortes. El llamado de Roux a que combinen el "pragmatismo" (es decir, la supervivencia y el fortalecimiento de la institución) y los "principios" no nos lleva muy lejos porque no es claro qué significa que una corte actúe con base en principios ni cómo debería elegir entre vías diferentes que parezcan ser de principios ${ }^{278}$. Necesitamos algo más específico, y el análisis de las instituciones políticas da pautas al respecto.

La Corte colombiana, por ejemplo, no puede confiar en la división institucional de poderes para disciplinar su trabajo porque el legislativo no tiene un papel claro en el sistema político. En cambio, la Corte se debe evaluar con base en si está ayudando a lograr la transformación constitucional, acercando a la política y a la sociedad colombianas al orden concebido en el texto de 1991. La Corte puede hacerlo de dos maneras básicas: primera, puede intentar una transformación sustantiva directa de aspectos del orden social para que correspondan con la visión constitucional; segunda, puede tratar de transformar las instituciones políticas, con lo cual estaría en mejor posición para lograr la transformación constitucional. Ambas son muy difíciles. La primera, porque la Corte colombiana, como cualquier otra, tiene límites en su capacidad institucional y en lo que puede lograr por sí misma. Puede intervenir en algunas áreas importantes de política, pero hay muchas cosas que no puede emprender porque no tiene tiempo ni capacidad. La segunda es igualmente difícil porque, como ya se explicó, la Corte

\footnotetext{
276 Roux (ibíd., 116-118) teoriza que la protección de "seguridad institucional" es importante cuando se evalúa la labor judicial en las nuevas democracias.

277 Ibíd., 107.

278 Ver ibíd. (116-118), donde se argumenta que las nuevas cortes deberían adoptar una mezcla del principio de Posner y del pragmatismo de Dworkin para construir legitimidad y asegurar la supervivencia institucional.
} 
tiene pocas palancas para mejorar la función del sistema de partidos $\mathrm{y}$ de instituciones representativas.

Sin embargo, parece ser que la Corte ha logrado algunos avances en ambas direcciones. Ha logrado directamente muchos cambios de política y la mayor parte de esos cambios parece congruente con la visión de la Constitución de 1991. Al mismo tiempo, sus intervenciones de alto perfil parecen haber ayudado a difundir las normas constitucionales entre el público en su conjunto y entre un grupo cada vez más poderoso de entidades gubernamentales de vigilancia, y de la sociedad civil. Además, su labor para ayudar a grupos tradicionalmente desvalidos a ganar acceso al sistema puede aumentar la legitimidad de la democracia ${ }^{279}$. Pero no es claro que la difusión de los valores constitucionales o el aumento de la legitimidad democrática mejoren realmente el desempeño de las instituciones democráticas en el largo plazo; la esperanza sería que el público y grupos valerosos de la sociedad civil puedan presionar a los representantes para que sean más receptivos a la democracia y más respetuosos de la Constitución. Algunos estudiosos sugieren que la labor de la Corte es contraproducente para la construcción de mejores instituciones políticas porque excluye la posibilidad del debate democrático sobre asuntos constitucionales controversiales ${ }^{280}$. Esto me parece dudoso para Colombia hoy en día, porque los actores políticos tienen poco interés en la Constitución. Pero la preocupación puede ser relevante en el largo plazo, y apuntaría a una reducción del papel de la Corte, como en Hungría.

Sea como fuere, aquí no me propongo dar una valoración definitiva de la labor de la Corte; esa tarea está fuera del alcance de este artículo. El punto, en cambio, es debatir la legitimidad de la jurisprudencia de la revisión judicial y constitucional en las nuevas democracias en sus propios términos, no con ideas prestadas de la teoría estadounidense. Los estudiosos del derecho constitucional comparado podemos hacer un aporte importante identificando el tipo de tareas que las cortes constitucionales pueden realizar en condiciones institucionales muy diferentes de la nuestra. No es fácil construir una teoría comparada

279 Faundez $(2005,761)$.

280 "Bien se puede argumentar que la Corte suplanta el debate político, lo que confirma el argumento de quienes piensan que la revisión judicial es antidemocrática" (ibíd., 761-762). Tushnet (2002, 57-65) describe el impacto del "vuelo judicial". Esto refleja un argumento de los constitucionalistas populares estadounidenses, quienes afirman que el activismo judicial, en particular la supremacía judicial, reduce el incentivo de los actores políticos para tomar en serio la Constitución. La diferencia en Estados Unidos es, por supuesto, que la Constitución es un instrumento importante en la cultura popular y es comúnmente invocada por los políticos.

Revista de Economía Institucional, vol. I3, n. ${ }^{\circ} 24$, Primer semestre/2oit, Pp. I3-83 
del rol judicial, y quizá ésta no dé respuestas claras, pero puede ayudar a guiar nuestras valoraciones del diseño constitucional y de las tareas de las cortes constitucionales en las nuevas democracias.

\section{REFERENCIAS BIBLIOGRÁFICAS}

1. Ackerman, B. We the People: Foundations, Cambridge, Harvard University Press, 1991.

2. Ágh, A. "Partial consolidation of the East-Central European parties: The case of the Hungarian Socialist Party", Party Politics 1, 4, 1995, pp. 491-514.

3. Archer, R. P. y M. S. Shugart. "The unrealized potential of presidential dominance in Colombia”, S. Mainwaring y M. S. Shugart, eds., Presidentialism and democracy in Latin America, New York, Cambridge University Press, 1997.

4. Baar, C. "Social action litigation in India: Operation and limitations of the world's most active judiciary", Policy Studies Journal 19, 1, 1990, pp. 140-150.

5. Bauman, R. W. y T. Kahana. The least examined branch: The role of legislatures in the Constitutional State, Cambridge, Cambridge University Press, 2006.

6. Berat, L. "The Constitutional Court of South Africa and jurisdictional questions: In the interest of justice?", International Journal of Constitutional Law 3, 1, 2005, pp. 39-76.

7. Bickel, A. The least dangerous branch: The Supreme Court at the bar of politics, $2^{\text {nd }}$ ed., New Haven, Yale University Press, 1986.

8. Bickel, A. The Supreme Court and the idea of progress, New Haven, Yale University Press, 1978.

9. Borón, A. A. "Latin America: Constitutionalism and the political traditions of liberalism and socialism", D. Greenberg et al., eds., Constitutionalism and Democracy: Transitions in the contemporary world, New York, Oxford University Press, 1993.

10. Bushnell, D. The making of modern Colombia: A nation in spite of itself, Berkeley, University of California Press, 1993.

11. Cárdenas, M. et al. "Political institutions and policy outcomes in Colombia: The effects of the 1991 Constitution”, E. Stein y M. Tommasi, eds., Policymaking in Latin America: How politics shapes policies, Washington, Inter-American Development Bank, 2008.

12. Carey J. M. y M. S. Shugart. "Incentives to cultivate a personal vote: A rank ordering of electoral formulas", Electoral Studies 14, 4, 1995, pp. 417-439.

13. Cepeda E., M. J. "How far may Colombia's Constitutional Court go to protect IDP rights", 2008 [http://www.fmreview.org/text/FMR/ BrookingsSpecial/13.pdf].

14. Cepeda E., M. J. "Judicial activism in a violent context: The origin, role, and impact of the Colombian Constitutional Court", Washington University Global Studies Law Review 3, special edition, 2004.

15. Cepeda E., M. J. Polémicas constitucionales, Bogotá, Legis, 2007. 
16. Cepeda E., M. J. Introducción a la Constitución de 1991: hacia un nuevo constitucionalismo, Bogotá, Presidencia de la Republica, 1993.

17. Cepeda U., F. "Colombia: Democratic security and political reform”, J. I. Domínguez y M. Shifter, eds., Constructing democratic governance in Latin America, Baltimore, Johns Hopkins University Press, 2008.

18. Clavijo, S. "Fallos y fallas económicas de la Corte Constitucional: E1 caso se Colombia 1991-2000”, 45, 2001 [http://www.hacer.org/pdf/ clavijo.pdf].

19. Conaghan, C. M. "Loose parties, 'floating' politicians, and institutional stress: Presidentialism in Ecuador, 1979-1988", J. J. Linz y A. Valenzuela, eds., The failure of presidential democracy: The case of Latin America, Baltimore, Johns Hopkins University Press, 1994.

20. Corte Constitucional. Sentencias-Tutelas 1992-2008, Bogotá, DMS Ediciones e Investigaciones, 2009.

21. Cox, G. W. y M. D. McCubbins, Leviathan Legislative, 1993.

22. Cox, G. W. y S. Morgenstern. "Epilogue: Latin America's reactive assemblies and proactive presidents", S. Morgenstern y B. Nacif, eds., Legislative politics in Latin America, Cambridge, Cambridge University Press, 2002.

23. Crisp, B. F. "The nature of representation in Andean legislatures and attempts at institutional reengineering", S. Mainwaring et al., eds., The crisis of democratic representation in the Andes, Stanford, Stanford University Press, 2006.

24. Currie, D. P. The Constitution of the Federal Republic of Germany, Chicago, University of Chicago Press, 1994.

25. Czarnota, A. et al., eds. Rethinking the rule of law after communism, New York, Central European University Press, 2005.

26. Devins, N. y A. Meese. "Judicial review and non-generalizable cases", Florida State University Law Review 32, 2, 2005, pp. 323-355.

27. Dieter-K., H. Parties, policies, and democracy, 1994.

28. Dorf, M. C. y Ch. F. Sabel. "A constitution of democratic experimentalism”, Columbia Law Review 98, 2, 1998, pp. 267-473.

29. Dugard, J. y T. Roux. "The record of the South African Constitutional Court in providing an Institutional Voice for the poor: 1995-2004", R. Gargarella et al., eds., Courts and social transformation in new democracies: an institutional voice for the poor?, Aldershot, Ashgate Publishing, 2006.

30. Dupré, C. Importing the law in post-communist transitions: The Hungarian Constitutional Court and the right to human dignity, Oxford, Hart Publishing, 2003.

31. Easterday, J. "Litigation or legislation: Protecting the rights of internally displaced persons in Colombia”, 2008 [http://works.bepress.com/ jennifer_easterday/1/].

32. Echavarría, J. J. et al. "Recent economic history of Colombia, A. Alesina, ed., Institutional reforms: The case of Colombia, Cambridge, MIT Press, 2005.

33. Elmendorf, Ch. S. "Advisory counterparts to constitutional courts", Duke Law Journal 56, 4, 2007, pp. 953-1045. 
34. Ely, J. H. Democracy and distrust, Cambridge, Harvard University Press, 1980.

35. Eskridge, W. N. y J. Ferejohn. "Super-statutes: The new American constitutionalism", R. W. Bauman y T. Kahana, eds., The least examined branch: The role of legislatures in the Constitutional State, Cambridge, Cambridge University Press, 2006.

36. Falla C., F. E. "Algunas consideraciones sobre el principio democrático y la función legislativa parlamentaria en Colombia”, Primeras Jornadas de Derecho Constitucional y Administrativo, Bogotá, Universidad Externado de Colombia, 2001.

37. Faundez, J. "Democratization through law: Perspectives from Latin America", Democratization 12, 5, 2005, pp. 749-765.

38. Finkel, J. Judicial reform as political insurance: Argentina, Peru, and Mexico in the 1990s, Notre Dame, University of Notre Dame Press, 2008.

39. Friedman, S. "No easy stroll to dominance", H. Giliomee y Ch. Simkins, eds., The awkward embrace: One-party domination and democracy, Cape Town, Tafelberg Press, 1999.

40. Fuller, L. "The forms and limits of adjudication", Harvard Law Review 92, 2, 1978, pp. 353-409.

41. Gamarra, E. A. y J. M. Malloy. "The patrimonial dynamics of party politics in Bolivia”, S. Mainwaring y T. Scully, eds., Building democratic institutions: Party systems in Latin America, Stanford, Stanford University Press, 1996.

42. García J., L. "Diálogo con dos profesores colombianos. Catalina Botero Marino y Mauricio García Villegas”, Revista Argentina de Teoría Jurídica 8, 1, 2007.

43. Gargarella, R. et al., eds. Courts and social transformation in new democracies: An institutional voice for the poor?, Aldershot, Ashgate Publishing, 2006.

44. Giliomee, H. "South Africa's emerging dominant-party regime", Journal of Democracy 9, 4, 1998, pp. 128-142.

45. Giliomee, H. et al. "Dominant party rule, opposition parties and minorities in South Africa”, Democratization 8, 1, 2001, pp. 161-182.

46. Giliomee, H. y Ch. Simkins, eds. The awkward embrace: One-party domination and democracy, Cape Town, Tafelberg, 1999.

47. Giliomee, H. y Ch. Simkins. "The dominant party regimes of South Africa, Mexico, Taiwan and Malaysia: A comparative assessment", The awkward embrace: One-party domination and democracy, Cape Town, Tafelberg, 1999a.

48. Gloppen, S. et al., eds. Democratization and the judiciary: The accountability function of courts in new democracies, London, Frank Cass, 2004.

49. Halmai, G. "The transformation of Hungarian constitutional law from 1985 to 2005", A. Jakab et al., eds., The transformation of the Hungarian legal order 1985-2005, The Hague, Kluwer Law International, 2007.

50. Helmke, G. Courts under constraints: Judges, generals, and presidents in Argentina, New York, Cambridge University Press, 2005. 
51. Hibbing, J. R. "Legislative careers: Why and how we should study them”, G. Loewenberg et al., eds., Legislatures: Comparative perspectives on representative assemblies, Ann Arbor, The University of Michigan Press, 2002.

52. Holmes, S. Passions and constraint: On the theory of liberal democracy, Chicago y London, University of Chicago Press, 1995.

53. Ilonszki, G. "Representation deficit in a new democracy: Theoretical considerations and the Hungarian case", Communist and PostCommunist Studies 31, 2, 1998, pp. 157-170.

54. Julio E., A. Las ramas ejecutiva y judicial del poder público en la Constitución colombiana de 1991, Bogotá, Universidad Externado de Colombia, 2003.

55. Kalmanovitz K., S. "La Corte Constitucional y la capitalización de intereses", 2000 [http://www.banrep.gov.co/documentos/presentacionesdiscursos/pdf/K-Corteycapitalizacion.pdf].

56. Kende, M. S. “The South African Constitutional Court's embrace of socio-economic rights: A comparative perspective", Chapman Law Review 6, 1, 2003, pp. 137-160.

57. Klug, H. Constituting democracy: Law, globalism and South Africa's political reconstruction, Cambridge, Cambridge University Press, 2000.

58. Kramer, L. "Putting the politics back into the political safeguards of federalism”, Columbia Law Review 100, 1, 2000, pp. 215-293.

59. Kramer, L. The people themselves: Popular constitutionalism and judicial review, New York, Oxford University Press, 2004.

60. Krehbiel, K. Information and legislative organization, Ann Arbor, University of Michigan Press, 1991.

61. Kugler, M. y H. Rosenthal. "Checks and balances: An assessment of the institutional separation of political powers in Colombia", A. Alesina, ed., Institutional reforms: The case of Colombia, Cambridge, MIT Press, 2005.

62. Lanegran, K. "South Africa's 1999 election: Consolidating a dominant party system”, Africa Today 48, 2, 2001, pp. 81-102.

63. Levinson, D. "Empire-building government in constitutional law", Harvard Law Review 118, 3, 2005, pp. 915-972.

64. Levinson, D. y R. Pildes. "Separation of parties, not powers", Harvard Law Review 119, 8, 2006, pp. 2311-2386.

65. López, C. y O. Sevillano. "Balance político de la parapolítica”, Corporación Nuevo Arco Iris, 14 de diciembre de 2008 [http://www. nuevoarcoiris.org.co/sac/files/arcanos/arcanos_14_diciembre_2008_files/ arcanos_14_informe_parapolitica.pdf].

66. Mainwaring S. y M. S. Shugart, eds. Presidentialism and Democracy in Latin America, Cambridge, Cambridge University Press, 1997.

67. Mainwaring, S. et al., eds. The crisis of democratic representation in the Andes, Stanford, Stanford University Press, 2006.

68. Mainwaring, S. et al. "The crisis of democratic representation in the Andes: An overview", The crisis of democratic representation in the Andes, Stanford, Stanford University Press, 2006a. 
69. Mainwaring, S. y M. S. Shugart, "Conclusion", Presidentialism and Democracy in Latin America, Cambridge, Cambridge University Press, 1997a.

70. Mainwaring, S. y T. R. Scully, eds. Building democratic institutions: Party systems in Latin America, Stanford, Stanford University Press, 1996.

71. Mainwaring, S. y T. R. Scully. "The dominant party regimes of South Africa, Mexico, Taiwan and Malaysia: A comparative assessment", Building democratic institutions: Party systems in Latin America, Stanford, Stanford University Press, 1966.

72. McCubbins, M. D. et al. "Structure and process, politics and policy: Administrative arrangements and the political control of agencies", Virginia Law Review 75, 2, 1989, pp. 431-482.

73. Moreno, E. "Whither the Colombian two-party system? An assessment of political reforms and their limits", Electoral Studies 24, 3, 2005, pp. 485-509.

74. Morgenstern, S. "Toward a model of Latin American legislatures", S. Morgenstern y B. Nacif, eds., Legislative politics in Latin America, Cambridge, Cambridge University Press, 2002.

75. Müller, J.-W. Constitutional patriotism, Princeton, Princeton University Press, 2007.

76. Navia, P. y J. Ríos-F. “The constitutional adjudication mosaic of Latin America”, Comparative Political Studies 38, 2, 2005, pp. 189-217.

77. O'Donnell, G. "Horizontal accountability in new democracies", A. Schedler et al., eds., The self-restraining state: Power and accountability in new democracies, Boulder, Lynne Rienner, 1999.

78. Okoth O., H. W. O. "Constitutions without constitutionalism: Reflections on an african political paradox", D. Greenberg et al., eds., Constitutionalism and Democracy: Transitions in the contemporary world, New York, Oxford University Press, 1993.

79. Olson, D. M. "Party formation and party system consolidation in the new democracies of Central Europe”, Political Studies 46, 3, 1998, pp. 432-464.

80. Palacio, M. y F. Safford. Colombia: Fragmented land, divided society, New York, Oxford University Press, 2002.

81. Pegram, T. "Accountability in hostile times: The case of the Peruvian Human Rights Ombudsman 1996-2001", Journal of Latin American Studies 40, 1, 2008, pp. 51-82.

82. Pizarro L., E. "Giants with feet of clay: Political parties in Colombia”, S. Mainwaring et al., The crisis of democratic representation in the Andes, Stanford, Stanford University Press, 2006.

83. Racz, B. e I. Kukorelli. “The 'Second-generation' post-communist elections in Hungary in 1994", Europe-Asia Studies 47, 2, 1995, pp. 251-279.

84. Ramseyer, J. M. y E. B. Rasmusen. Measuring judicial independence: The political economy of judging in Japan, Chicago, The University of Chicago, 2003.

85. Ray, B. "Policentrism, political mobilization and the promise of socioeconomic rights", Stanford Journal of International Law 45, 1, 2009, pp. 151-201. 
86. Revenga S. M. y E. Girón R. “La Corte Constitucional colombiana ante las medidas de seguridad y defensa nacional del gobierno de Uribe", Estudios Socio-Jurídicos 6, 1, 2004, pp. 29-57.

87. Rosenberg, G. R. The hollow hope: Can courts bring about social change?, Chicago, The University of Chicago, 1991.

88. Rosenkrantz, C. "Against borrowings and other non-authoritative uses of foreign law", International Journal of Constitutional Law 1, 2, 2003, pp. 269-295.

89. Rosenn, K. "Brazil's new Constitution: An exercise in transient constitutionalism for a transitional society", The American Journal of Comparative Law 38, 4, 1990, pp. 773-802.

90. Roux, T. "Legitimating transformation: Political resource allocation in the South African Constitutional Court”, S. Gloppen et al., eds., Democratization and the judiciary: The accountability function of courts in new democracies, London, Frank Cass, 2004.

91. Roux, T. "Principle and pragmatism on the Constitutional Court of South Africa", International Journal of Constitutional Law 7, 1, 2009, pp. 106-138.

92. Roux, T. "Understanding Grootboom - A response to Cass R. Sunstein", Constitutional Forum 12, 2, 2002, pp. 112-122.

93. Sachs, A. "The judicial enforcement of socio-economic rights: The Grootboom case”, P. Jones y K. Stokke, eds., Democratising development: The politics of socio-economic rights in South Africa, Boston, Martinus Nijhoff Publishers, 2005.

94. Sajó, A. "Social rights as middle class entitlements in Hungary: The role of the Constitutional Court", R. Gargarella et al., eds., Courts and social transformation in new democracies: An institutional voice for the poor?, Aldershot, Ashgate Publishing, 2006.

95. Schedler, A. "The menu of manipulation", Journal of Democracy 13, 2, 2002, pp. 36-50.

96. Scheppele, K. L. "A realpolitik defense of social rights", Texas Law Review 82, 7, 2004, pp. 1921-1962.

97. Scheppele, K. L. "Democracy by judiciary: Or, why courts can be more democratic than parliaments", A. Czarnota et al., eds., Rethinking the rule of law after communism, New York, Central European University Press, 2005.

98. Schor, M. "Constitutionalism through the looking glass of Latin America”, Texas International Law Journal 41, 1, 2006, pp. 1-38.

99. Schwartz, H. The struggle for constitutional justice in post-communist Europe, Chicago, The University of Chicago Press, 2000.

100. Segura, R. y A. M. Bejarano. “ ¡Ni una asamblea más sin nosotros! Exclusion, inclusion, and the politics of constitution-making in the Andes”, Constellations 11, 2, 2004, pp. 217-236.

101. Shugart, M. S., E. Moreno y L. Fajardo. "Deepening democracy by renovating political practices: The struggle for electoral reform in Colombia”, C. Welna y G. Gallón, eds., Peace, democracy, and buman rights in Colombia, Notre Dame, University of Notre Dame Press, 2007. 
102. Simkins, Ch. "Stability and competitiveness in the political configurations of semi-developed countries”, H. Giliomee y Ch. Simkins, eds., The awkward embrace: One-party domination and democracy, Cape Town, Tafelberg, 1999.

103. Skach, C. "Rethinking judicial review", A. Czarnota et al., eds., Rethinking the rule of law after communism, New York, Central European University Press, 2005.

104. Slaughter, A. M. "Human Rights International Law Symposium Article: A typology of transjudicial communication”, University of Richmond Law Review 29, 1994, pp. 99-137.

105. Solyom, L. y G. Brunner, eds. Constitutional judiciary in a new democracy: The Hungarian Constitutional Court, Ann Arbor, University of Michigan Press, 2000.

106. Stephenson, M. "When the devil turns: The political foundations of independent judicial review", Journal of Legal Studies 32, 1, 2003, pp. 59-89.

107. Stoke, S. C. Mandates and democracy: Neoliberalism by surprise in Latin America, New York, Cambridge University Press, 2001.

108. Sunstein, C. "Interest groups in American public law", Stanford Law Review 38, 1, 1985, pp. 29-87.

109. Sunstein, C. "Nondelegation canons", University of Chicago Law Review 67, 2, 2000, pp. 315-343.

110. Sunstein, C. Designing democracy: What constitutions do, Oxford, Oxford University Press, 2001.

111. Thayer, J. B. "The origin and scope of the American doctrine of judicial review", Harvard Law Review 7, 1893, pp 129-152.

112. Toole, J. "Government formation and party system stabilization in East Central Europe”, Party Politics 6, 4, 2000, pp. 441-461.

113. Tsebelis, G. Veto players: How political institutions work, Princeton, Princeton University Press, 2002.

114. Tushnet, M. “The political constitution of emergency powers", Minnesota Law Review 91, 5, 2007, pp. 1451-1472.

115. Tushnet, M. "The possibilities of comparative constitutional law: Some lessons from Hamdan", Yale Law Journal 108, 6, 1999a, pp. 1225-1309.

116. Tushnet, M. Taking the Constitution away from the Courts, Princeton, Princeton University Press, 1999.

117. Tushnet, M. Weak courts, strong rights: Judicial review and social welfare in comparative constitutional law, Princeton, Princeton. University Press, 2008.

118. Uprimny Y., R. "The enforcement of social rights by the Colombian Constitutional Court: Cases and debates", R. Gargarella et al., eds., Courts and social transformation in new democracies: An institutional voice for the poor?, Aldershot, Ashgate Publishing, 2006.

119. Uprimny Y., R. y D. Guarnizo. “¿Es posible una dogmática adecuada sobre la prohibición de regresividad? Un enfoque desde la jurisprudencia constitucional colombiana?”, Dejusticia, 30 junio de 2006 [www.dejusticia.org/interna.php?id_tipo_publicacion=2\&id_ publicacion $=180]$. 
120. Uprimny Y., R. “The Constitutional Court and control of presidential emergency powers in Colombia", S. Gloppen et al., eds., Democratization and the judiciary: The accountability function of courts in new democracies, London, Frank Cass, 2004.

121. Uprimny Y., R. y M. P. Saffon. "Desplazamiento forzado y justicia transicional en Colombia", Dejusticia, 30 de agosto de 2006 [http://www.dejusticia.org/interna.php?id_tipo_publicacion=2\&id_ publicacion $=184]$.

122. Vermeule, A. Judging under uncertainty: An institutional theory of legal interpretation, Cambridge, Harvard University Press, 2006.

123. Vila C., I. Nuevo derecho constitucional: antecedentes y fundamentos, Bogotá, Ediciones Jurídicas Gustavo Ibáñez, 2002.

124. Waldron, J. "The core of the case against judicial review", Yale Law Journal 115, 6, 2006, pp. 1346-1406.

125. Watson, A. Legal transplants: An approach to comparative law, Athens, University of Georgia Press, 1993.

126. Weinrib, L. E. “The postwar paradigm and American exceptionalism”, S. Choudhry, ed., The migration of constitutional ideas, Cambridge, Cambridge University Press, 2006.

127. Whittington, K. E. “Extrajudicial constitutional interpretation: Three objections and responses", North Carolina Law Review 80, 3, 2002, pp. 773-851.

128. Whittington, K. E. Constitutional construction: Divided powers and constitutional meaning, Cambridge, Harvard University Press, 1999.

129. Whittington, K. E. et al. "The Constitution and congressional committees: 1971-2000”, R. W. Bauman y T. Kahana, eds., The least examined branch: The role of legislatures in the Constitutional State, Cambridge, Cambridge University Press, 2006.

130. Widner, J. A. Building the rule of law: Francis Nyalali and the road to judicial independence in Africa, New York, W. W. Norton, 2001.

131. Woolman, S. “The amazing, vanishing bill of rights”, South African Law Journal 124, 4, 2007, pp. 762-794.

132. Zweigert, K. y H. Kotz. An introduction to comparative law, Oxford, Clarendon Press, 1998. 